\title{
Optimization of the Extraction and Stability of Antioxidative Peptides from Mackerel (Pneumatophorus japonicus) Protein
}

\author{
Xueqin Wang, Huahua Yu, Ronge Xing, Xiaolin Chen, Song Liu, and Pengcheng Li \\ Institute of Oceanology, Chinese Academy of Sciences, Qingdao 266071, China \\ Correspondence should be addressed to Pengcheng Li; pcli@qdio.ac.cn
}

Received 30 September 2016; Revised 7 December 2016; Accepted 18 December 2016; Published 17 January 2017

Academic Editor: Kazim Husain

Copyright (C) 2017 Xueqin Wang et al. This is an open access article distributed under the Creative Commons Attribution License, which permits unrestricted use, distribution, and reproduction in any medium, provided the original work is properly cited.

\begin{abstract}
This study optimizes the preparation conditions for mackerel protein hydrolysate (MPH) by response surface methodology (RSM) and investigates the stability of the antioxidant activity of MPHs $(<2.5 \mathrm{kDa})$. The optimal conditions were as follows: enzyme concentration of $1726.85 \mathrm{U} / \mathrm{g}, \mathrm{pH}$ of 7.00 , temperature of $39.55^{\circ} \mathrm{C}$, time of $5.5 \mathrm{~h}$, and water/material ratio of $25: 1$, and the maximum DPPH scavenging activity was $79.14 \%$. The MPHs indicated significant cellular antioxidant activity at low concentrations. Furthermore, the temperature and freeze-thaw cycles had little effect on the antioxidative stability while $\mathrm{pH}$ had significant effect on the antioxidative stability. In addition, the MPHs were sensitive to the metal ions, such as $\mathrm{Fe}^{2+}, \mathrm{Fe}^{3+}, \mathrm{Zn}^{2+}$, and $\mathrm{Cu}^{2+}$. Notably, when the concentrations of $\mathrm{Fe}^{2+}$ and $\mathrm{Fe}^{3+}$ were $5 \mathrm{mM}$, the DPPH scavenging activities were only $1.1 \%$ and $0.6 \%$, respectively; furthermore, $\mathrm{Cu}^{2+}$ at a $5 \mathrm{mM}$ concentration could completely inhibit the DPPH scavenging activity of MPHs. In contrast, $\mathrm{K}^{+}$and $\mathrm{Mg}^{2+}$ had no notable effect on the antioxidant activity of MPHs. These results may provide a scientific basis for the processing and application of MPHs.
\end{abstract}

\section{Introduction}

In recent years, there has been increasing interest in finding natural antioxidants, because they can protect the human body from free radicals and retard the progress of many chronic diseases [1]. Many plant and animal sources have been found to possess antioxidant activity, such as Psidium guajava leaves [2], soybean protein [3], sheep, and pig blood [4]. Marine organisms are receiving more attention because of their special structure and living environment; notably, a number of studies have been conducted using fish protein hydrolysates as antioxidant peptides, like cod, tuna, salmon, and so on [5-7]. Mackerel (Pneumatophorus japonicus) is a kind of pelagic fish which has the characteristics of low economic and high productivity, and how to best utilize these positive characteristics of mackerel needs to be addressed. In recent years, there have been many researches on the processing and utilization of mackerel; for example, Donnelly et al. [8] found the cost and benefits of traceability system implementation both electronically and practically in a mackerel supply chain between Japan and Norway; in addition, the research of lipid oxidation and fishy odor development in protein hydrolysates from the muscle of Indian mackerel was reported [9]; Ferraro et al. [10] also discussed the mackerel canning residues; and Sheriff et al. [11] investigated the hydrolysate from backbones of Indian mackerel, revealing that the hydrolysate contained potent antioxidants and exhibited significant reducing power, free radical scavenging activity, and lipid peroxidation inhibition.

Response surface methodology (RSM) is a statistical multifactorial analysis of experimental variables and response, which offers a better understanding of the experimental process [12]. Besides, RSM as an effective statistical model has been widely used in pharmaceutical and functional foods research [13]. In recently years, RSM model has been widely applied to fish protein [14-16] extraction. For example, Shi et al. [17] has optimized processing parameters of horse mackerel (Trachurus japonicus) dried in a heat pump dehumidifier under the conditions from RSM model; Wang et al. [18] studied the hydrolysis conditions for the production of iron-binding peptides from mackerel processing byproducts under the experimental process through RSM system. However, there has been little investigation into the optimization of antioxidative peptide extraction from mackerel. 
While various antioxidant peptides have been isolated from different fish proteins, most research has focused on the relationship between their structure and function. To the best of our knowledge, little is known about the effects on the antioxidant activity of peptides of processing and storage conditions, such as temperature, light, $\mathrm{pH}$, phenols, and metals [19]. These factors may affect the bioactivity of peptides and limit their application in food field. Furthermore, the amino acid composition of peptide is complex and may be degraded through deamidation, oxidation, hydrolysis, and cyclization reactions during processing and storage, leading to the loss of antioxidant activity [20]. As an example, high temperatures may alter peptide structures, and the target peptide can be degraded into fragments, thereby losing the antioxidant activity [21]. On the other hand, drying of hydrolysates at high temperature may not destroy the biological activity of peptides [22]. Consequently, it is important to study factors that might affect the stability of the antioxidant activity of peptides during processing and storage.

In our prior work, five proteases (trypsin, papain, neutrase, acid protease, and flavourzyme) were used for hydrolysis to select the optimal mackerel protein hydrolysate (MPH), and the results showed that the hydrolysate produced by neutrase $\left(1.0 \times 10^{5} \mathrm{U} / \mathrm{g}\right)$ exhibited the highest DPPH scavenging activity (35.9\%) and degree of hydrolysate (15.9\%). In this article, we would optimize conditions for the extraction of $\mathrm{MPH}$ by the single factor experiment and RSM. Furthermore, in our previous study, we examined the antioxidant activity of different molecular weights of $\mathrm{MPH}$ and found that the fractions with molecular weight below $2.5 \mathrm{kDa}$ exhibited the strongest antioxidant activity [23]. Thus, this paper also presents cellular antioxidant activity and the stability of antioxidant activity of MPHs $(<2.5 \mathrm{kDa})$.

\section{Material and Methods}

Fresh mackerel (Pneumatophorus japonicus), 210-260 g/fish, was purchased from a seafood market in Qingdao, China. Whole fish were transported on ice to reduce histamine producing. Upon arrival, the fish were washed and the flesh (without head, tail, skin, bones, and blood) was collected, sliced, minced, and stored in plastic bags at $-20^{\circ} \mathrm{C}$ until use. Five proteases (trypsin, papain, neutrase, acid protease, and flavourzyme) were provided by Kangbaotai Co. (Hubei, China). 1,1-Diphenyl-2-picrylhydrazyl (DPPH) and 3,5-ditert-4-butylhydroxytoluene (BHT) were purchased from Sigma Chemical Co. (St. Louis, MO, USA). The ultrafiltration (UF) system and UF membranes with $2500 \mathrm{Da}$ molecular weight cutoffs were purchased from Laungy Co. Ltd. (Shanghai, China). The growth medium and antibiotics for the cell culture experiments were purchased from Hyclone, USA; serum was purchased from Gibco, Australian. All other chemicals and solvents were of analytical grade.

\subsection{Preparation of Mackerel Protein Hydrolysates}

2.1.1. Single Factor Experiments. In this section, the neutrasetreated hydrolysate was chosen as the best candidate [23], and five major factors (enzyme concentration, $\mathrm{pH}$, extraction temperature, extraction time, and water/material ratio) were selected for the single factor experiments. The mackerel muscle was mixed with deionized water at a various of water/material ratio, and the mixtures were adjusted to the required $\mathrm{pH}$ with $0.01 \mathrm{~mol} / \mathrm{L} \mathrm{NaOH}$ or $\mathrm{HCl}$ and heated in a water bath to the required temperature before the neutrase was added in proper proportion based on its activity, and the hydrolysis reactions were carried out in a shaking incubator. At the end of the hydrolysis period, the mixtures were heated in boiling water for $10 \mathrm{~min}$ to inactivate the proteases. Then the hydrolysates were centrifuged at $18000 \times \mathrm{g}$ $\left(4^{\circ} \mathrm{C}\right)$ for $30 \mathrm{~min}$ and the supernatants or dried powders by freeze dryer were used for DPPH radical scavenging activity. It is worth mentioning that the DPPH radical scavenging assay, which is simple and accurate, has been widely used to evaluate antioxidative properties of compounds as free radical scavengers or hydrogen donors [24-26].

2.1.2. Scavenging Activity on DPPH Radicals. The DPPH radical scavenging activities of the MPH supernatant were determined as described by Chen et al. [27] with slight modifications. Briefly, $1.0 \mathrm{~mL}$ of DPPH $(0.1 \mathrm{mmol} / \mathrm{L})$ diluted in ethanol was added to $3.0 \mathrm{~mL}$ of $\mathrm{MPH}$ supernatant. After vigorous shaking, the mixture was left to stand for $30 \mathrm{~min}$ and the absorbance was measured at $517 \mathrm{~nm}$. The $\mathrm{DPPH}$ radical scavenging activity was calculated as follows: scavenging rate $(\%)=\left[1-\left(A_{1}-A_{0}\right) /\left(A_{2}-A_{0}\right)\right] \times 100$, where $A_{0}$ was the absorbance without DPPH, $A_{1}$ was the absorbance in the presence of the MPH supernatant, and $A_{2}$ was the absorbance of the control (without sample). All experiments were performed in triplicate.

2.1.3. Scavenging Activity on Hydroxyl Radical. Scavenging activity of MPH supernatant on hydroxyl radicals was performed, using method described by You et al. [28], with a few modifications. Briefly, the reaction mixture contained $1.0 \mathrm{~mL}$ of phosphate buffer (PBS, $0.15 \mathrm{~mol} / \mathrm{L}, \mathrm{pH} 7.4$ ), $1.0 \mathrm{~mL}$ of safranin $\mathrm{T}(1.0 \mathrm{mM}), 0.5 \mathrm{~mL}$ of EDTA-FeSO $(2.0 \mathrm{mmol} / \mathrm{L})$, and $1.0 \mathrm{~mL}$ of $\mathrm{MPH}$ supernatant. After sufficient mixing, $1.0 \mathrm{~mL}$ of $\mathrm{H}_{2} \mathrm{O}_{2}(3 \%)$ was added to the mixture. Following incubation at $37^{\circ} \mathrm{C}$ for $30 \mathrm{~min}$, the absorbance of the mixture was measured at $520 \mathrm{~nm}$. The hydroxyl radical scavenging activity was calculated as scavenging rate $(\%)=\left[\left(A_{1}-\right.\right.$ $\left.\left.A_{0}\right) /\left(A_{2}-A_{0}\right)\right] \times 100$, where $A_{1}$ was the absorbance of the $\mathrm{MPH}$ supernatant, $A_{2}$ was the absorbance without $\mathrm{H}_{2} \mathrm{O}_{2}$, and $A_{0}$ was the absorbance of the control. Both $A_{0}$ and $A_{2}$ were the mixtures with sample solution replaced by deionized water. All experiments were performed in triplicate.

\subsubsection{Optimization of MPH Preparative Conditions by RSM.} On the basis of the single factor experiments, the five independent variables at five levels were employed in a central composite experimental design (CCD). The five independent variables (enzyme concentration, $\mathrm{pH}$, extraction temperature, extraction time, and water/material ratio) were coded as $X_{1}, X_{2}, X_{3}, X_{4}$, and $X_{5}$, respectively. The ranges and levels of the variables are given in Table 1 , and the complete design 
TABLE 1: Independent variables and their levels in CCD.

\begin{tabular}{lccccc}
\hline Variables & Code & -2 & -1 & Levels and range & \multicolumn{2}{c}{. } \\
\hline Enzyme concentration $(\mathrm{U} / \mathrm{g})$ & $X_{1}$ & 1200 & 1400 & 1600 & 1800 \\
$\mathrm{pH}$ & $X_{2}$ & 5.5 & 6 & 6.5 & 7 \\
Extraction temperature $\left({ }^{\circ} \mathrm{C}\right)$ & $X_{3}$ & 30 & 35 & 40 & 7.5 \\
Extraction time $(\mathrm{h})$ & $X_{4}$ & 4 & 4.5 & 5 & 5000 \\
Water/material ratio $(\mathrm{w} / \mathrm{w})$ & $X_{5}$ & 10 & 15 & 20 & 5.5 \\
\hline
\end{tabular}

consisted of 50 combinations including eight replicates of the center points.

The responses obtained from each set of experimental designs were analyzed by multiple regressions to fit the following quadratic polynomial model:

$$
Y=\beta_{0}+\sum_{i=1}^{k} \beta_{i} X_{i}+\sum_{i=1}^{k} \beta_{i i} X_{i}^{2}+\sum \sum_{i<j} \beta_{i j} X_{i} X_{j}
$$

where $Y$ is the response variable, $\beta_{0}$ is a constant, and $\beta_{i}, \beta_{i i}$, and $\beta_{i j}$ are the linear, quadratic, and interaction coefficients, respectively, while $X_{i}$ and $X_{j}$ are the coded independent variables [26].

Design-Expert 8.0 (Stat-Ease, Inc., China) was used to analyze and calculate the predicted responses and experimental design for the DPPH scavenging activity. The analysis of variance table was generated, and the effect and regression coefficients of linear, quadratic, and interaction terms were determined. The statistical significance for each term in the polynomial was determined by computing the $F$ value at a probability $P$ of 0.05 . The regression coefficient was used to perform statistical calculations and the generated 3D surface was from the fitted polynomial equation.

\subsection{Antioxidant Analyses in HepG2 Cells}

2.2.1. Cytotoxicity. The inhibition of HepG2 was assessed by the MTT assay described by Chen et al. [29] with a few modifications. The HepG2 cells were seeded into 96well culture plates $\left(4 \times 10^{3}-1 \times 10^{4} /\right.$ well $)$ and incubated at $37^{\circ} \mathrm{C}$ in a humidified atmosphere with $5 \% \mathrm{CO}_{2}$ for $24 \mathrm{~h}$, then the HepG2 cells were incubated with MPHs at different concentrations $(0.5,1,2.5,5,10,15$, and $20 \mathrm{mg} / \mathrm{mL}$ and $100 \mu \mathrm{L})$ for $24 \mathrm{~h}$, and the cells without the MPHs were used as a negative control. Then, $20 \mu \mathrm{L}$ of MTT $(5 \mathrm{mg} / \mathrm{mL})$ was added to each well and the plates were incubated for $3 \mathrm{~h}$. After the removal of MTT, dimethyl sulfoxide (DMSO) $(150 \mu \mathrm{L} /$ well) was added and shaken for $10 \mathrm{~min}$; then the absorbance was measured on a microplate reader (Bio-Rad, USA) at a wavelength of $490 \mathrm{~nm}$. Measurements were performed 4 times and the inhibition of HepG2 was evaluated.

2.2.2. Cellular Antioxidant Activity. Cells were placed in a 96well plate $\left(4 \times 10^{3}-1 \times 10^{4} /\right.$ well $)$ and incubated at $37^{\circ} \mathrm{C}$ in a humidified atmosphere with $5 \% \mathrm{CO}_{2}$ for $24 \mathrm{~h}$. Then cells were treated with MPHs at different concentrations $(0.05,0.1,0.25$, $0.5,1,2,2.5$, and $5 \mathrm{mg} / \mathrm{mL}$ and $100 \mu \mathrm{L}$ ) for $24 \mathrm{~h}$, after which the cells were treated with $1000 \mu \mathrm{M} \mathrm{H}_{2} \mathrm{O}_{2}(100 \mu \mathrm{L})$ for another
$24 \mathrm{~h}$, and the cellular antioxidant activity of MPHs was tested with MTT assay as described above. The cells without the $\mathrm{H}_{2} \mathrm{O}_{2}$ used as a negative control and the measurements were performed 4 times.

\subsection{Stability of the Antioxidant Activity of MPHs}

2.3.1. Effect of Temperature on the Antioxidant Activity of MPHs. To determine the appropriate temperature range for processing and storage, the MPHs $(5 \mathrm{mg} / \mathrm{mL})$ was incubated at $-4,20,36,60,80$, and $100^{\circ} \mathrm{C}$ for $2 \mathrm{~h}$, the condition of $-4^{\circ} \mathrm{C}$ was controlled by fridge, and the other temperatures were controlled by water bath. After the specified time, the sample was immediately cooled in iced water, then centrifuged at $18000 \times \mathrm{g}\left(4^{\circ} \mathrm{C}\right)$ for $30 \mathrm{~min}$, and subsequently evaluated for DPPH and hydroxyl radical scavenging activities.

2.3.2. Effect of $p H$ on the Antioxidant Activity of MPHs. The $\mathrm{pH}$ range selected for the present study was from 2.2 to 9.2. The $\mathrm{pH}$ of the MPHs was adjusted using $1 \mathrm{M} \mathrm{NaOH}$ or $1 \mathrm{M} \mathrm{HCl}$, and the MPHs $(5 \mathrm{mg} / \mathrm{mL})$ was maintained at room temperature for $2 \mathrm{~h}$. After the specified time, each sample was centrifuged and the DPPH and hydroxyl radical scavenging activities were determined.

2.3.3. Effect of the Freeze-Thaw Cycle on the Antioxidant Activity of MPHs. The MPHs $(5 \mathrm{mg} / \mathrm{mL})$ was frozen at $-80^{\circ} \mathrm{C}$ for $2 \mathrm{~h}$ firstly and then unfrozen with the running water at room temperature, which was defined as the first cycle. The second cycle was repeat frozen and unfrozen and so on. The sample was centrifuged and the DPPH and hydroxyl radical scavenging activities were determined to illustrate the effect of freeze-thaw cycle on the stability of MPHs.

2.3.4. Effect of Metal Ions on the Antioxidant Activity of MPHs. The effect of metal ions on the antioxidant activity of MPHs was studied by the addition of $20 \mathrm{mM}$ solutions of $\mathrm{K}^{+}, \mathrm{Zn}^{2+}, \mathrm{Ca}^{2+}, \mathrm{Fe}^{2+}, \mathrm{Fe}^{3+}, \mathrm{Mg}^{2+}$, and $\mathrm{Cu}^{2+}$ from $\mathrm{KCl}$, $\mathrm{ZnCl}_{2}, \mathrm{CaCl}_{2}, \mathrm{FeCl}_{2}, \mathrm{FeCl}_{3}, \mathrm{MgCl}_{2}$, and $\mathrm{CuCl}_{2}$, respectively. Each metal ion was added in appropriate quantities to attain final concentrations of $0.1,0.5,1.0,2.0,3.0,4.0$, and $5.0 \mathrm{mM}$, respectively. The mixtures were incubated at room temperature for $2 \mathrm{~h}$, and the DPPH and hydroxyl radical scavenging activities were measured.

2.4. Statistical Analysis. All tests were conducted in triplicate. The experimental data were expressed as the mean \pm standard 


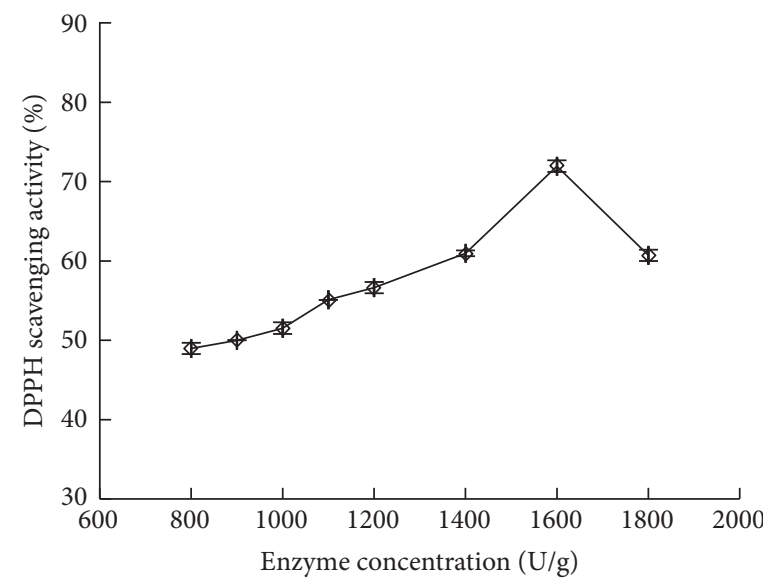

(a)

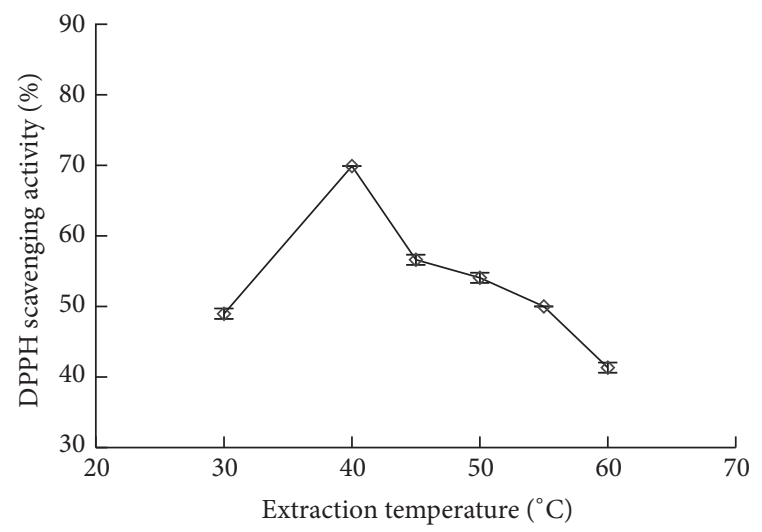

(c)

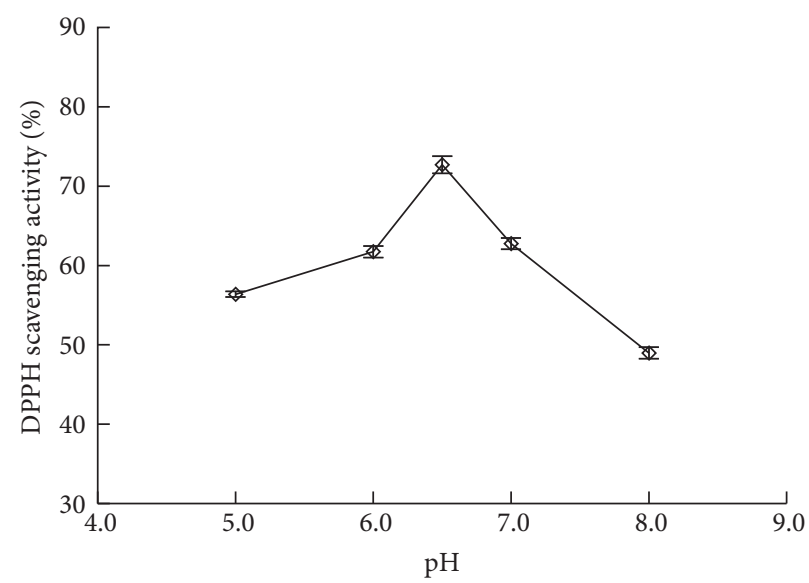

(b)

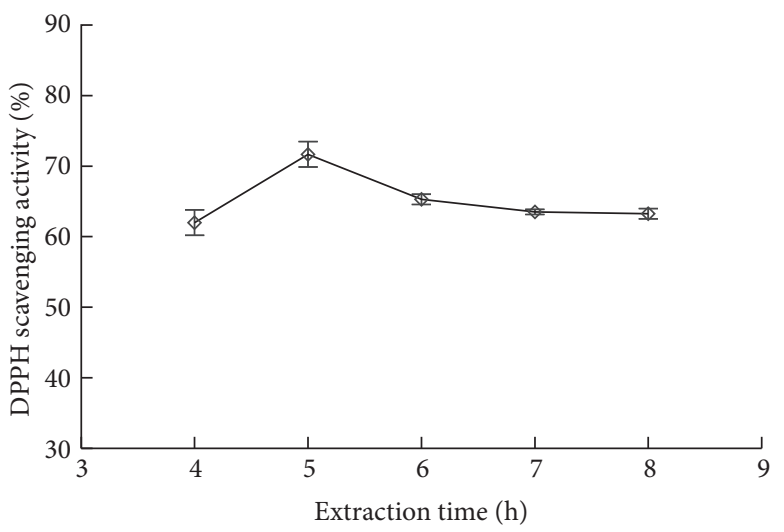

(d)

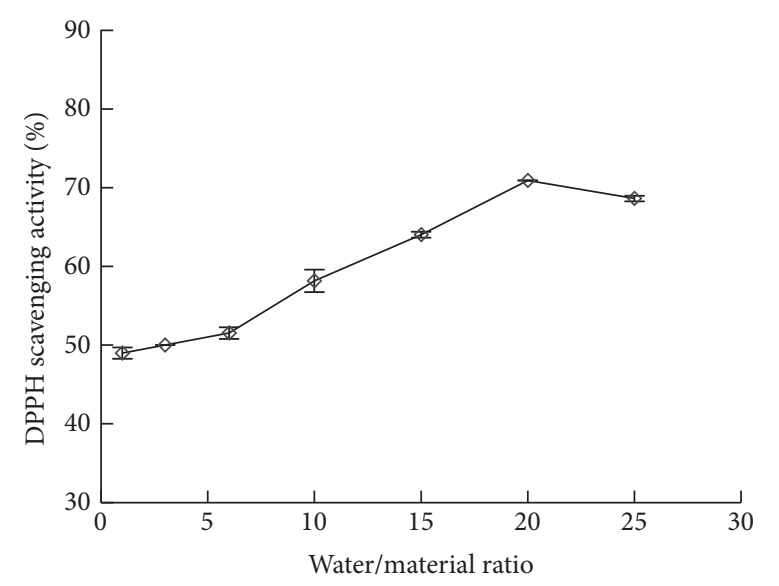

(e)

Figure 1: Effects of five single factors on the DPPH scavenging activity.

error. LSD and Duncan tests were performed to determine the significant differences between samples within a $95 \%$ confidence interval, using SPSS 18.0 statistical software (IBM, USA).

\section{Results and Discussion}

3.1. Single Factor Experiments. In this work, the effects of five single factors on the DPPH scavenging activity were investigated (Figure 1), the result showed that, under the range of five single factors, the DPPH scavenging activity increased at first and then decreased; then the optimal conditions are displayed: enzyme concentration of $1600 \mathrm{U} / \mathrm{g}$, $\mathrm{pH}$ of 6.5, extraction temperature of $40^{\circ} \mathrm{C}$, extraction time of $5.0 \mathrm{~h}$, and water/material ratio of $20: 1$.

3.2. Optimization of Extraction Conditions by CCD. According to the single factor experiments, the design matrix and 
TABLE 2: Experimental design and result of response surface.

\begin{tabular}{|c|c|c|c|c|c|c|}
\hline Run numbers & $\begin{array}{c}X_{1}: \text { enzyme } \\
\text { concentration }(\mathrm{U} / \mathrm{g})\end{array}$ & $X_{2}: \mathrm{pH}$ & $\begin{array}{c}X_{3}: \text { extraction } \\
\text { temperature }\left({ }^{\circ} \mathrm{C}\right)\end{array}$ & $X_{4}:$ extraction time $(\mathrm{h})$ & $\begin{array}{l}X_{5}: \text { water/material } \\
\text { ratio }(\mathrm{w} / \mathrm{w})\end{array}$ & Response (\%) \\
\hline 1 & 1400 & 6 & 35 & 4.5 & 15 & 57.84 \\
\hline 2 & 1800 & 6 & 35 & 4.5 & 15 & 59.73 \\
\hline 3 & 1400 & 7 & 35 & 4.5 & 15 & 58.38 \\
\hline 4 & 1800 & 7 & 35 & 4.5 & 15 & 60.54 \\
\hline 5 & 1400 & 6 & 45 & 4.5 & 15 & 62.97 \\
\hline 6 & 1800 & 6 & 45 & 4.5 & 15 & 66.49 \\
\hline 7 & 1400 & 7 & 45 & 4.5 & 15 & 65.14 \\
\hline 8 & 1800 & 7 & 45 & 4.5 & 15 & 68.11 \\
\hline 9 & 1400 & 6 & 35 & 5.5 & 15 & 53.51 \\
\hline 10 & 1800 & 6 & 35 & 5.5 & 15 & 56.22 \\
\hline 11 & 1400 & 7 & 35 & 5.5 & 15 & 55.68 \\
\hline 12 & 1800 & 7 & 35 & 5.5 & 15 & 59.46 \\
\hline 13 & 1400 & 6 & 45 & 5.5 & 15 & 61.08 \\
\hline 14 & 1800 & 6 & 45 & 5.5 & 15 & 63.24 \\
\hline 15 & 1400 & 7 & 45 & 5.5 & 15 & 64.59 \\
\hline 16 & 1800 & 7 & 45 & 5.5 & 15 & 67.57 \\
\hline 17 & 1400 & 6 & 35 & 4.5 & 25 & 64.59 \\
\hline 18 & 1800 & 6 & 35 & 4.5 & 25 & 68.11 \\
\hline 19 & 1400 & 7 & 35 & 4.5 & 25 & 69.73 \\
\hline 20 & 1800 & 7 & 35 & 4.5 & 25 & 72.16 \\
\hline 21 & 1400 & 6 & 45 & 4.5 & 25 & 69.46 \\
\hline 22 & 1800 & 6 & 45 & 4.5 & 25 & 70.00 \\
\hline 23 & 1400 & 7 & 45 & 4.5 & 25 & 70.81 \\
\hline 24 & 1800 & 7 & 45 & 4.5 & 25 & 71.89 \\
\hline 25 & 1400 & 6 & 35 & 5.5 & 25 & 69.19 \\
\hline 26 & 1800 & 6 & 35 & 5.5 & 25 & 72.16 \\
\hline 27 & 1400 & 7 & 35 & 5.5 & 25 & 72.43 \\
\hline 28 & 1800 & 7 & 35 & 5.5 & 25 & 81.62 \\
\hline 29 & 1400 & 6 & 45 & 5.5 & 25 & 71.35 \\
\hline 30 & 1800 & 6 & 45 & 5.5 & 25 & 74.86 \\
\hline 31 & 1400 & 7 & 45 & 5.5 & 25 & 72.16 \\
\hline 32 & 1800 & 7 & 45 & 5.5 & 25 & 75.41 \\
\hline 33 & 1200 & 6.5 & 40 & 5 & 20 & 63.51 \\
\hline 34 & 2000 & 6.5 & 40 & 5 & 20 & 66.22 \\
\hline 35 & 1600 & 5.5 & 40 & 5 & 20 & 71.35 \\
\hline 36 & 1600 & 7.5 & 40 & 5 & 20 & 72.97 \\
\hline 37 & 1600 & 6.5 & 30 & 5 & 20 & 61.89 \\
\hline 38 & 1600 & 6.5 & 50 & 5 & 20 & 71.62 \\
\hline 39 & 1600 & 6.5 & 40 & 4 & 20 & 65.68 \\
\hline 40 & 1600 & 6.5 & 40 & 6 & 20 & 72.97 \\
\hline 41 & 1600 & 6.5 & 40 & 5 & 10 & 52.97 \\
\hline 42 & 1600 & 6.5 & 40 & 5 & 30 & 74.05 \\
\hline 43 & 1600 & 6.5 & 40 & 5 & 20 & 74.59 \\
\hline 44 & 1600 & 6.5 & 40 & 5 & 20 & 74.05 \\
\hline 45 & 1600 & 6.5 & 40 & 5 & 20 & 71.35 \\
\hline 46 & 1600 & 6.5 & 40 & 5 & 20 & 71.35 \\
\hline 47 & 1600 & 6.5 & 40 & 5 & 20 & 70.81 \\
\hline 48 & 1600 & 6.5 & 40 & 5 & 20 & 70.27 \\
\hline 49 & 1600 & 6.5 & 40 & 5 & 20 & 70.81 \\
\hline 50 & 1600 & 6.5 & 40 & 5 & 20 & 70.27 \\
\hline
\end{tabular}

corresponding results obtained from CCD for determining the effects of the five independent variables $\left(X_{1}, X_{2}, X_{3}, X_{4}\right.$, and $X_{5}$ ) were listed in Table 2.

These results showed that the DPPH scavenging activity ranged from $52.97 \%$ to $81.62 \%$. The data were analyzed via multiple regression analysis using Design-Expert software to yield the following polynomial equation:

$$
\begin{aligned}
Y= & -186.58+0.11 X_{1}-11.43 X_{2}+7.20 X_{3}+1.45 X_{4} \\
& +2.82 X_{5}+(2.20 E-003) X_{1} X_{2}
\end{aligned}
$$


TABLE 3: ANOVA for response surface quadratic model.

\begin{tabular}{|c|c|c|c|c|c|}
\hline Variables & Sum of squares & $\mathrm{DF}$ & Mean square & $F$ value & $P$ value \\
\hline Model & 1857.34 & 20 & 92.87 & 31.17 & $<0.0001$ \\
\hline$X_{1}$ & 73.05 & 1 & 73.05 & 24.52 & $<0.0001$ \\
\hline$X_{2}$ & 57.86 & 1 & 57.86 & 19.42 & $<0.0001$ \\
\hline$X_{3}$ & 173.24 & 1 & 173.24 & 58.15 & $<0.0001$ \\
\hline$X_{4}$ & 21.30 & 1 & 21.30 & 7.15 & 0.0122 \\
\hline$X_{5}$ & 1077.11 & 1 & 1077.11 & 361.56 & $<0.0001$ \\
\hline$X_{1} X_{2}$ & 1.54 & 1 & 1.54 & 0.52 & 0.4775 \\
\hline$X_{1} X_{3}$ & 2.34 & 1 & 2.34 & 0.78 & 0.3830 \\
\hline$X_{1} X_{4}$ & 4.83 & 1 & 4.83 & 1.62 & 0.2130 \\
\hline$X_{1} X_{5}$ & 0.58 & 1 & 0.58 & 0.20 & 0.6611 \\
\hline$X_{2} X_{3}$ & 4.83 & 1 & 4.83 & 1.62 & 0.2130 \\
\hline$X_{2} X_{4}$ & 2.96 & 1 & 2.96 & 0.99 & 0.3272 \\
\hline$X_{2} X_{5}$ & 2.05 & 1 & 2.05 & 0.69 & 0.4131 \\
\hline$X_{3} X_{4}$ & 0.45 & 1 & 0.45 & 0.15 & 0.7012 \\
\hline$X_{3} X_{5}$ & 84.15 & 1 & 84.15 & 28.25 & $<0.0001$ \\
\hline$X_{4} X_{5}$ & 78.97 & 1 & 78.97 & 26.51 & $<0.0001$ \\
\hline$X_{1}^{2}$ & 88.41 & 1 & 88.41 & 29.68 & $<0.0001$ \\
\hline$X_{2}^{2}$ & 0.84 & 1 & 0.84 & 0.28 & 0.5991 \\
\hline$X_{3}^{2}$ & 45.25 & 1 & 45.25 & 15.19 & 0.0005 \\
\hline$X_{4}^{2}$ & 9.59 & 1 & 9.59 & 3.22 & 0.0833 \\
\hline$X_{5}^{2}$ & 128.00 & 1 & 128.00 & 42.97 & $<0.0001$ \\
\hline Residual & 86.39 & 29 & 2.98 & & \\
\hline Lack of fit & 66.56 & 22 & 3.03 & 1.07 & 0.5010 \\
\hline Pure error & 19.83 & 7 & 2.83 & & \\
\hline Cor. total & 1943.74 & 49 & & & \\
\hline$R^{2}$ & 0.9556 & & & & \\
\hline Adj. $R^{2}$ & 0.9249 & & & & \\
\hline Pred. $R^{2}$ & 0.8591 & & & & \\
\hline Adeq. precision & 22.175 & & & & \\
\hline CV\% & 2.56 & & & & \\
\hline
\end{tabular}

$$
\begin{aligned}
& -(2.70 E-004) X_{1} X_{3}+(3.88 E-003) X_{1} X_{4} \\
& +(1.35 E-004) X_{1} X_{5}+0.16 X_{2} X_{3}+1.22 X_{2} X_{4} \\
& +0.10 X_{2} X_{5}+0.05 X_{3} X_{4}+0.06 X_{3} X_{5} \\
& +0.63 X_{4} X_{5}-(4.16 E-005) X_{1}^{2}-0.65 X_{2}^{2} \\
& -0.05 X_{3}{ }^{2}-2.19 X_{4}{ }^{2}-0.08 X_{5}{ }^{2}
\end{aligned}
$$

Analysis of variance (ANOVA) results for the model were given in Table 3 . The corresponding variables were more significant as the $F$ value became greater and the $P$ value became smaller [30]. It could be seen that the variables with the most significant effects on the DPPH scavenging activity of $\mathrm{MPH}$ were certain linear terms $\left(X_{1}, X_{2}, X_{3}\right.$, and $\left.X_{5}\right)$, quadratic terms $\left(X_{1}{ }^{2}, X_{3}{ }^{2}\right.$, and $\left.X_{5}{ }^{2}\right)$, and interaction terms $\left(X_{3} \times X_{5}\right.$ and $\left.X_{4} \times X_{5}\right)$. As seen in Table 3 , the model showed a good fit with the experimental data, with high values of $R^{2}$ (95.56\%) and Adj. $R^{2}(92.49 \%)$. The low coefficient value of the variation $(\mathrm{CV}=2.56 \%)$ clearly suggested a high degree of precision and reliability of the experimental values. This result implied that the hydrolysis process of MPH could be analyzed and predicted by the model.

The effects of variables and their interactions on $\mathrm{DPPH}$ scavenging activity were illustrated by $3 \mathrm{D}$ response surfaces. The figures displayed the effects of two factors on DPPH scavenging activity while the others were kept at a zero level [31].

Figure 2(a) showed that DPPH scavenging activity increased as the enzyme concentration was increased from 1200 to $1600 \mathrm{U} / \mathrm{g}$, but further higher enzyme concentration did not influence the DPPH scavenging activity. The excess enzyme might not participate in the reaction; on the contrary, they increased the concentration of reaction system and restricted the activity of free radical. When the $\mathrm{pH}$ increased from 5.5 to 7.5, DPPH scavenging activity had increased slightly, because each protein has different isoelectric point, and then the solubility of protein was affect by $\mathrm{pH}$ value.

As shown in Figure 2(b), at lower enzyme concentrations, when temperature increased, DPPH scavenging activity increased slightly; at higher enzyme concentrations, DPPH 
Design-Expert software

Factor coding: actual

DPPH scavenging activity

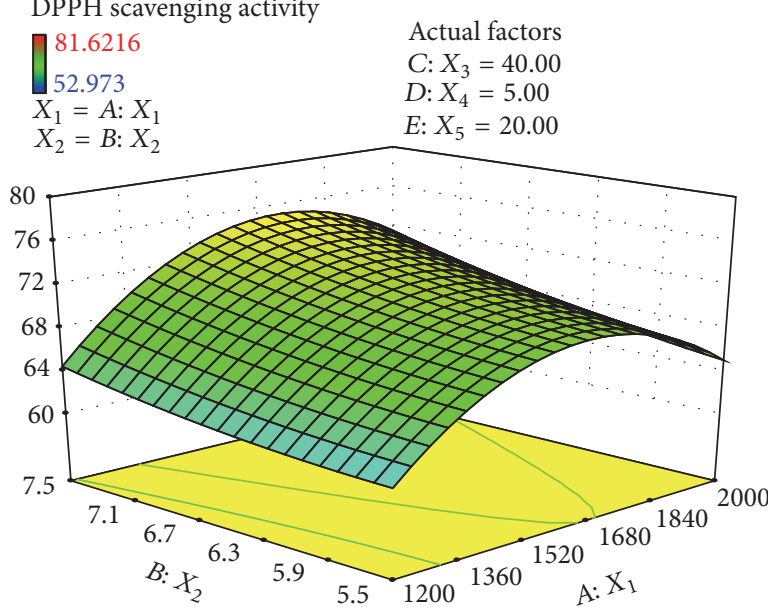

(a)

Design-Expert software

Factor coding: actual

DPPH scavenging activity

$\begin{array}{ll}\prod_{51.6216} & \text { Actual factors } \\ 52.973 & B: X_{2}=6.50 \\ X_{1}=A: X_{1} & C: X_{3}=40.00 \\ X_{2}=D: X_{4} & E: X_{5}=20.00\end{array}$

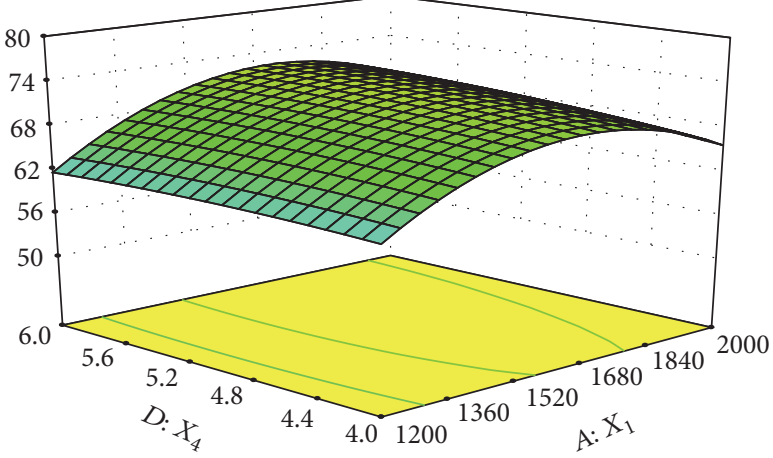

(c)

Design-Expert software

Factor coding: actual

DPPH scavenging activity

$\begin{array}{ll}\prod_{52.673} 1.6216 & \text { Actual factors } \\ \text { A: } X_{1}=1600.00 \\ X_{1}=B: X_{2} & D: X_{4}=5.00 \\ X_{2}=C: X_{3} & E: X_{5}=20.00\end{array}$

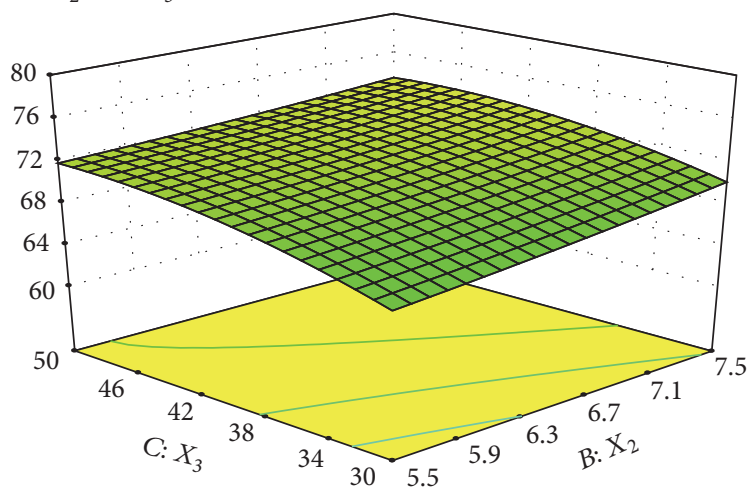

(e)
Design-Expert software

Factor coding: actual

DPPH scavenging activity

\begin{tabular}{ll}
\hline 1.6216 & Actual factors \\
52.973 & $B: X_{2}=6.50$ \\
$X_{1}=A: X_{1}$ & $D: X_{4}=5.00$ \\
$X_{2}=C: X_{3}$ & $E: X_{5}=20.00$
\end{tabular}

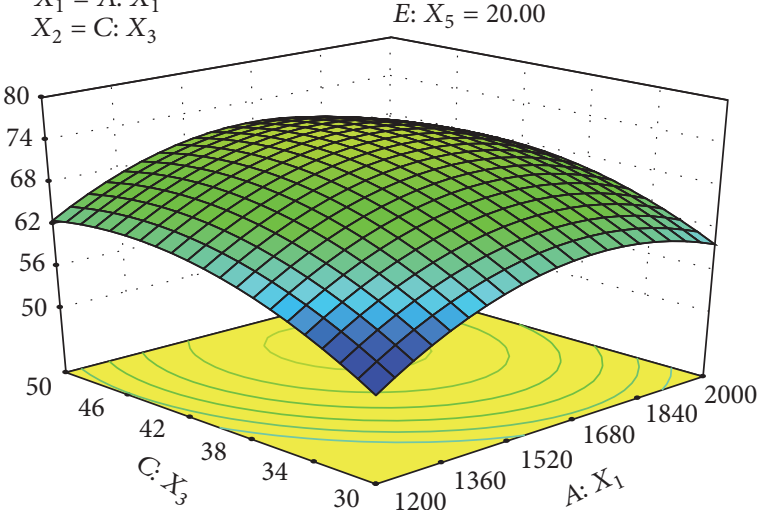

(b)

Design-Expert software

Factor coding: actual

DPPH scavenging activity

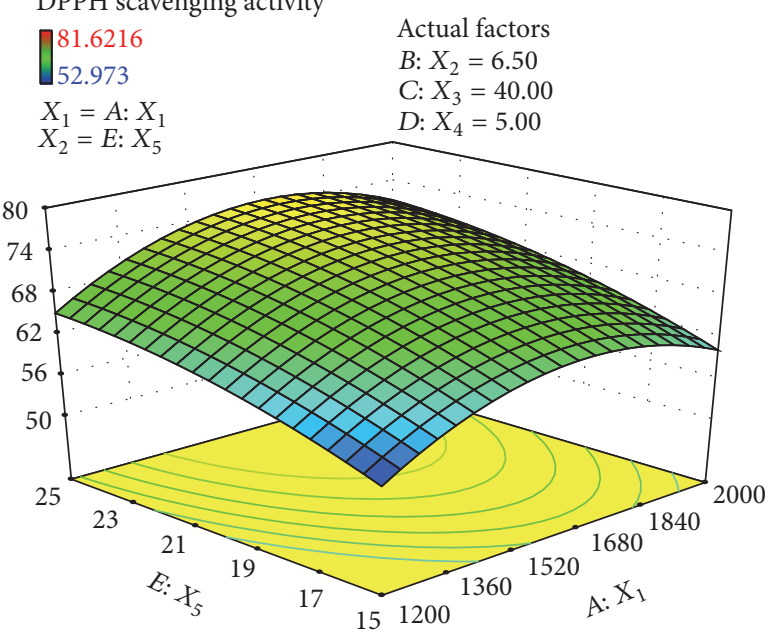

(d)

Design-Expert software

Factor coding: actual

DPPH scavenging activity
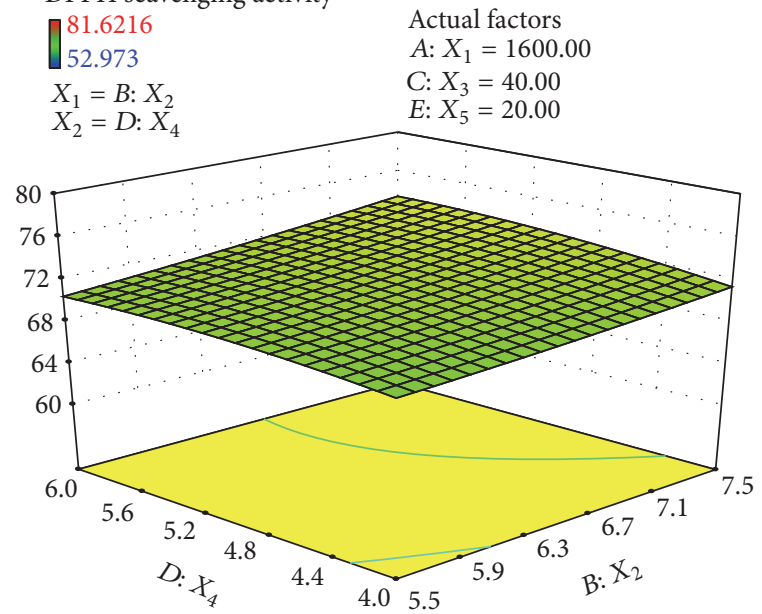

(f)

Figure 2: Continued. 


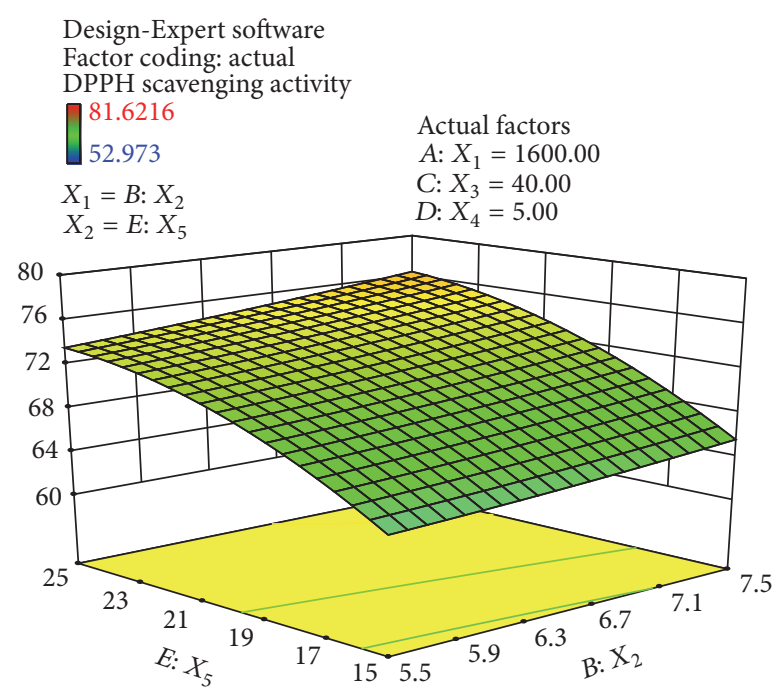

(g)

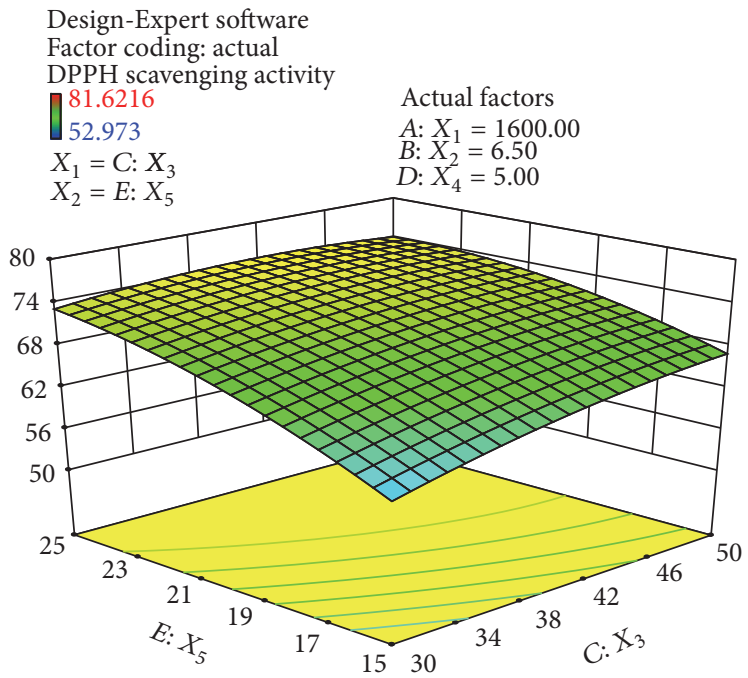

(i)

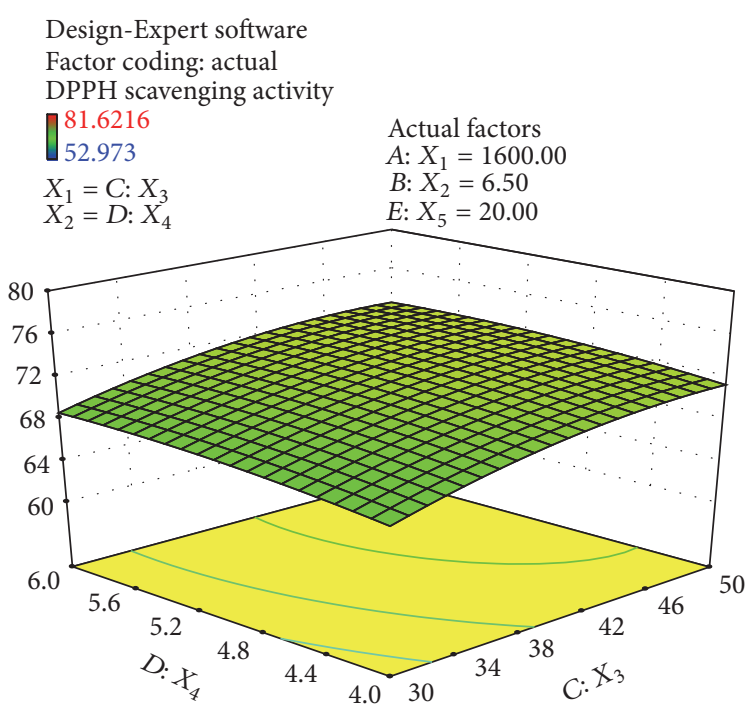

(h)
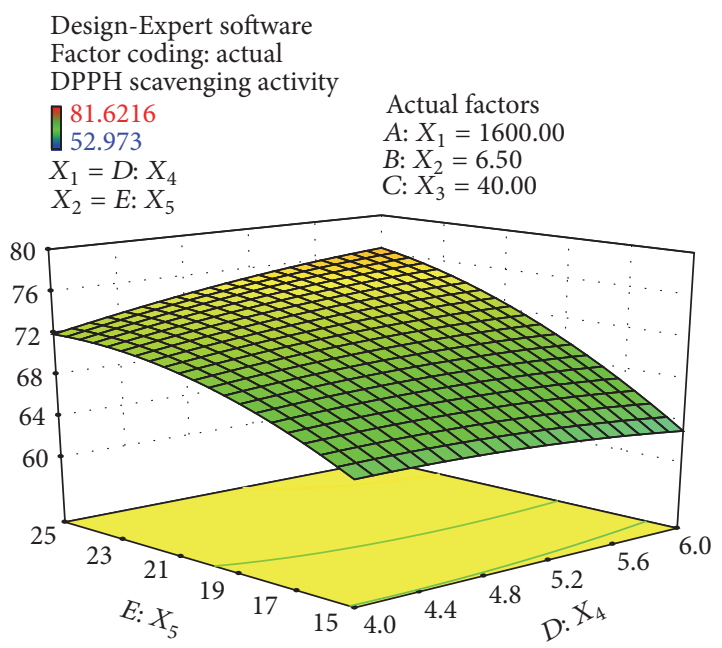

(j)

Figure 2: Response surface plots showing the effects of variables $\left(X_{1}\right.$ : enzyme concentration; $X_{2}: \mathrm{pH} ; X_{3}$ : extraction temperature; $X_{4}$ : extraction time; $X_{5}$ : water/material ratio) on the scavenging activity of MPH ( $y$-axis: DPPH scavenging activity).

scavenging activity increased slightly with temperature from 30 to $46^{\circ} \mathrm{C}$ and decreased slightly with temperature from 46 to $50^{\circ} \mathrm{C}$; the maximum DPPH scavenging activity was observed at about $46^{\circ} \mathrm{C}$. This was likely because the treatment at approximately $60^{\circ} \mathrm{C}$ would cause complete denaturation of the peptide [32], and high extraction temperatures may be due to denaturation and inactivation of enzymes and decrease the DPPH scavenging activity. In addition, when enzyme concentrations increased from 1200 to $1800 \mathrm{U} / \mathrm{g}$, DPPH scavenging activity increased significantly; maybe there are more enzymes molecules present in high enzyme concentration; there will be more chances for the hydrolysis to occur [33]; these result is agreed with Fang et al. [34], which found higher $\mathrm{DPPH}$ scavenging activity occurring at a high enzyme to substrate ratio. While when enzyme concentration increased from 1800 to $2000 \mathrm{U} / \mathrm{g}$, DPPH scavenging activity decreased slightly, we speculated that too high enzyme concentration may increase the concentration of system and limited the ion activity.

As shown in Figure 2(c), DPPH scavenging activity increased slightly when the extraction time increased from 4 to $5 \mathrm{~h}$ and then decreased slightly with an extraction time of $6 \mathrm{~h}$; we inferred that the hydrolysis reaction was powerful in the first four hours and became flat later. As shown in Figure 2(d), when the water/material ratio increased from 10 to $30, \mathrm{DPPH}$ scavenging activity increased significantly; some researchers have studied that increased water added to substrate enhanced enzyme homogeneity and reduced the localized concentration of hydrolysis products [35]. In addition, the DPPH scavenging activity increased firstly and decreased significantly with the enzyme concentrations from 1200 to $2000 \mathrm{U} / \mathrm{g}$; the result was the same as Figure 2(b).

As shown in Figure 2(e), when $\mathrm{pH}$ and temperature increased, DPPH scavenging activity increased slightly. 


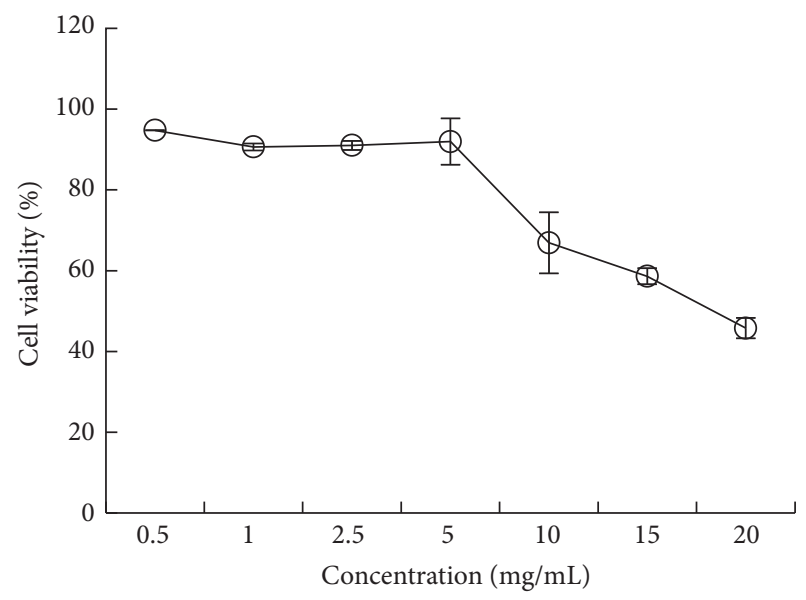

(a)

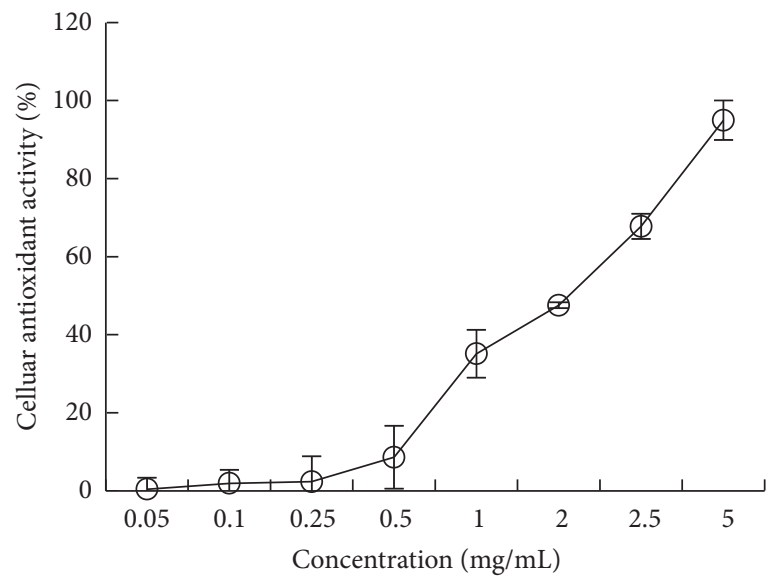

(b)

FIgURE 3: Cellular antioxidant activity of MPHs with various concentrations in HepG2 cells.

As shown in Figure 2(f), with the hydrolysis times increased from 4 to $6 \mathrm{~h}, \mathrm{DPPH}$ radical scavenging activity increased very slowly when $\mathrm{pH}$ increased. In addition, Figure 2(h) showed that DPPH scavenging activity increased slowly with the increase of temperature and extraction time. These results did not conclude that the factors had no effect on DPPH scavenging activity; in other words, we inferred that there was an interaction between the two factors in Figures 2(e), 2(f), and 2(h), because the DPPH scavenging activity was maintained at high value from about $68 \%$ to $73 \%$.

Figures 2(g), 2(i), and 2(j) showed that when the water/material ratio increased, DPPH scavenging activity increased significantly, which indicates that a relatively high water/material ratio is desirable to promote the antioxidant activity of hydrolysates. Figure 2(i) showed that, at lower water/material ratio, DPPH radical scavenging activity increased significantly when temperature increased; at higher water/material ratio, DPPH radical scavenging activity remains unchanged when temperature increased. Some researchers have explained that at lower temperatures, the rate of enzyme heat-inactivation was slower in comparison with the rate of the enzyme catalyzed reaction. At higher temperatures, the increased heat-inactivation rate led to a faster decrease in the number of active catalyst molecules [15]. Furthermore, Figure 2(j) showed that at lower water/material ratio, DPPH radical scavenging activity decreased slightly when hydrolysis times increased; at higher water/material ratio, DPPH radical scavenging activity increased slightly when hydrolysis times increased.

Using Design-Expert 8.0, the optimal hydrolysate conditions were enzyme concentration of $1726.85 \mathrm{U} / \mathrm{g}, \mathrm{pH}$ of 7.00 , temperature of $39.55^{\circ} \mathrm{C}$, extraction time of $5.5 \mathrm{~h}$, and water/material ratio of $25: 1$. The maximum DPPH scavenging activity was $79.14 \%$, which was in agreement with the experimental value $(79.19 \%)$ within a $99 \%$ confidence interval, suggesting a good fit between the model and experimental data.

3.3. Cytotoxicity Effects. Toxicity study was conducted to ascertain that the sample was safe for the proposed treatments on the HepG2 cells. The cellular antioxidant activity of MPHs in HepG2 cells was measured with concentrations of 0.5 , $1,2.5,5,10,15$, and $20 \mathrm{mg} / \mathrm{mL}$, respectively. After $24 \mathrm{~h}$ of incubation, the effect of MPHs on HepG2 cells viability was analyzed (Figure 3(a)); the results showed that the MPHs were relatively nontoxic to HepG2 cells at concentrations less than $5 \mathrm{mg} / \mathrm{mL}$, with cell viability more than $90 \%$; this was similar to the research by Kong et al. [36]. These preliminary analysis showed that MPHs had low toxicity at high concentrations. Figure 3(b) showed the cellular antioxidant activity of MPHs which with concentration from $0.05 \mathrm{mg} / \mathrm{mL}$ to $5 \mathrm{mg} / \mathrm{mL}$ was from $0.41 \%$ to $94.95 \%$, and the antioxidant activity of MPHs was significantly dependent on the concentrations.

Figures 4(a)-4(d) showed the image of the cells viewed under a light microscope. Figure 4 (b) showed $\mathrm{H}_{2} \mathrm{O}_{2}$-induced oxidative damage in the untreated HepG 2 cells, accompanied by the cell nucleus exposed. After pretreatment with MPHs ( $5 \mathrm{mg} / \mathrm{mL})$, the HepG2 cells caused significant inhibition of oxidative damage in Figure 4(c), which exhibited viability levels similar to those of the control group in Figure 4(a). However, when the cells were treated with MPHs at the concentration of $20 \mathrm{mg} / \mathrm{mL}$, the cells were seriously damaged, as Figure 4(d) showed that the cell nucleus was exposed, and the cells clustered, indicating that a high concentration of MPHs expressed cytotoxicity. The result showed that the MPHs exhibited significant cellular antioxidant activity within a certain concentration.

3.4. Stability of Antioxidant Activity of MPHs. Several protein hydrolysates derived from food protein have become important areas of research for health food [37]. In our prior work, MPHs $(<2.5 \mathrm{kDa})$ exhibited in vitro antioxidant activity and in vivo antifatigue effects [38], indicating that they could be used as natural antioxidants to enhance the antioxidant properties of functional foods. In contrast, only a few studies have examined the stability of peptide bioactivity. Some studies have reported that technological processes used in food manufacture affect the functional, nutritional, and biological properties of food protein [39]. Given these results, 

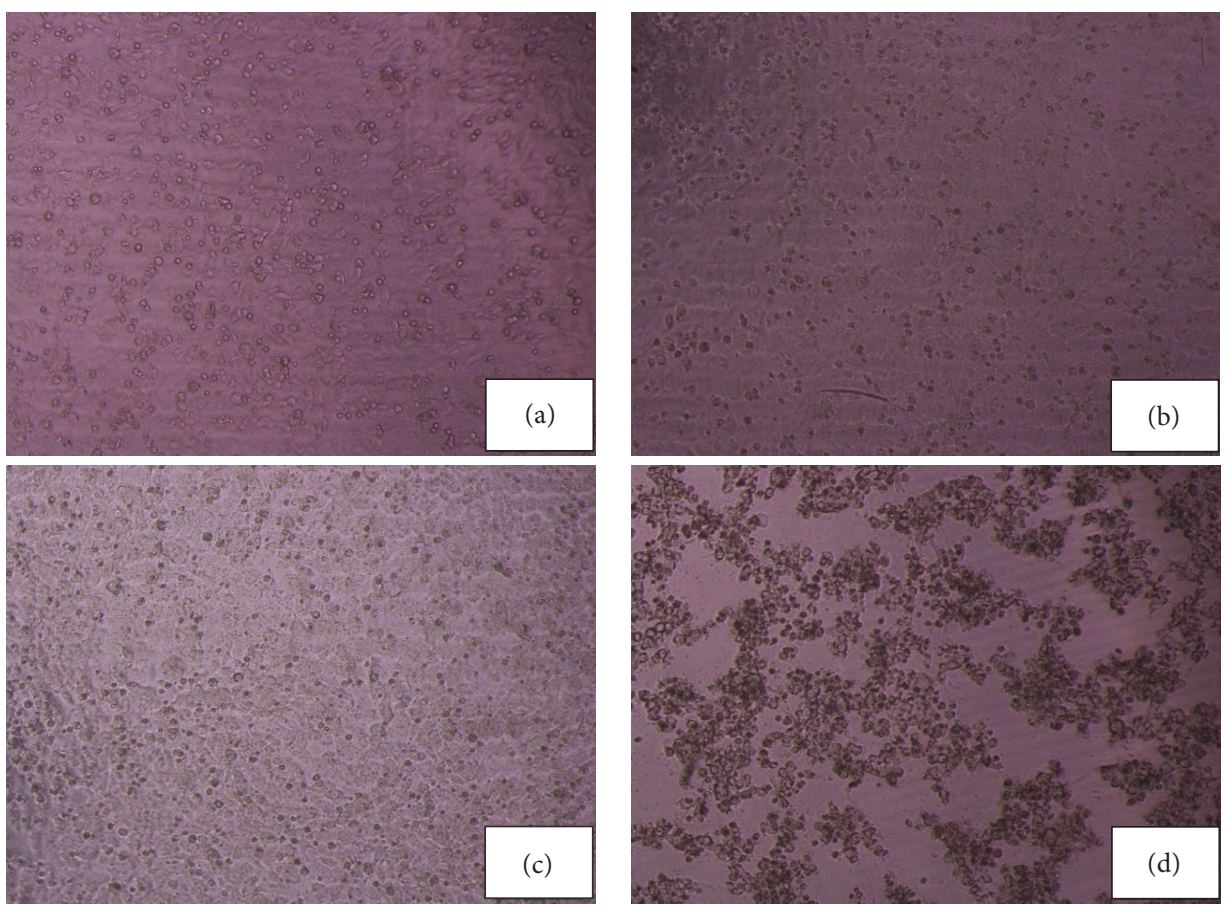

Figure 4: Morphological changes of HepG2 cells in response to untreatment, $\mathrm{H}_{2} \mathrm{O}_{2}(1000 \mu \mathrm{mol} / \mathrm{L}), \mathrm{MPHs}(5 \mathrm{mg} / \mathrm{mL})+\mathrm{H}_{2} \mathrm{O}_{2}$, and $\mathrm{MPHs}$ $(20 \mathrm{mg} / \mathrm{mL})+\mathrm{H}_{2} \mathrm{O}_{2}$, respectively. The images were captured using a digital camera attached to an inverted microscope.

it is necessary to study the effect of different factors, such as temperature, $\mathrm{pH}$, freeze-thaw frequency, $\mathrm{UV}$, and metal ions on the antioxidant activity of MPHs.

3.4.1. Effect of Temperature on the Antioxidant Activity of $M P H s$. Heat treatment is a general process in food manufacturing that can influence the functional properties of protein hydrolysates. During peptide processing, concentration and drying were examined, which are both processes related to temperature. As shown in Figure 5, the antioxidant activity of MPHs remained steady at temperatures of $-4,20,40$, and $60^{\circ} \mathrm{C}$. When the temperatures were 80 and $100^{\circ} \mathrm{C}$, the hydroxyl radical scavenging activity decreased slightly and DPPH radical scavenging activity increased slightly. Maybe the higher temperature leads to the protein denaturant and affects the antioxidant activity of MPHs. While the trends of hydroxyl radical scavenging activity and $\mathrm{DPPH}$ radical scavenging activity were different, we thought that there may be a little experiment error between them and need further research. In addition, Zhu et al. [20] have reported that the DPPH radical scavenging activity of peptides showed a sharp decline between 60 to $80^{\circ} \mathrm{C}$, potentially due to the high temperature affecting the secondary structure, which could lead to the instability of antioxidant activity; then with the temperature continue increasing, the DPPH scavenging activity becomes stable. While in our experimental temperature range, hydroxyl radical scavenging activity of MPHs was maintained at $75-80.2 \%$ and the DPPH radical scavenging activity was maintained at $86.5-90.2 \%$, respectively. This result indicated that the MPHs had good heat stability.
3.4.2. Effect of $p H$ on the Antioxidant Activity of MPHs. The antioxidant activity of MPHs at different $\mathrm{pH}$ values was shown in Figure 6. At pH levels from 2.2 to 7.2, MPHs exhibited strong antioxidant activity. However, when the $\mathrm{pH}$ was 9.2, the DPPH and hydroxyl radical antioxidant activity of MPHs declined sharply, exhibiting reductions of $90 \%$ and $16 \%$, respectively, compared with that under the $\mathrm{pH}$ of 2.2 . Some researchers have found that when peptide is in alkaline condition, it is likely that racemization reaction occurs and reduces the antioxidant activity of MPHs; furthermore, at high $\mathrm{pH}$ values, deamination reaction resulting in change with structure, conformation, and loss of antioxidant activity of peptides might occur [40,41]. Generally speaking, different peptides have different proper $\mathrm{pH}$ range, and they have high bioactivity during the $\mathrm{pH}$ range. Some other researchers have indicated that higher $\mathrm{pHs}$, specially from 9.0 on, will promote the amino-group ionization from amino acids and peptides, increasing the $\mathrm{H}^{+}$release and consequently enhancing the free radicals quenching, promoting the observed antioxidant activity [42]. In this section, the result showed that alkaline conditions were unfavorable for maintaining the antioxidant activity of MPHs.

3.4.3. Effect of the Freeze-Thaw Cycle on the Antioxidant Activity of MPHs. During transportation and storage, high temperature, long hours, and enzyme degradation may influence seafood, so the freezing technology has been successfully applied, such that the frozen storage is an important preservation method for seafood. Thanonkaew et al. [43] have determined that lipid oxidation of all treatments increased as the 


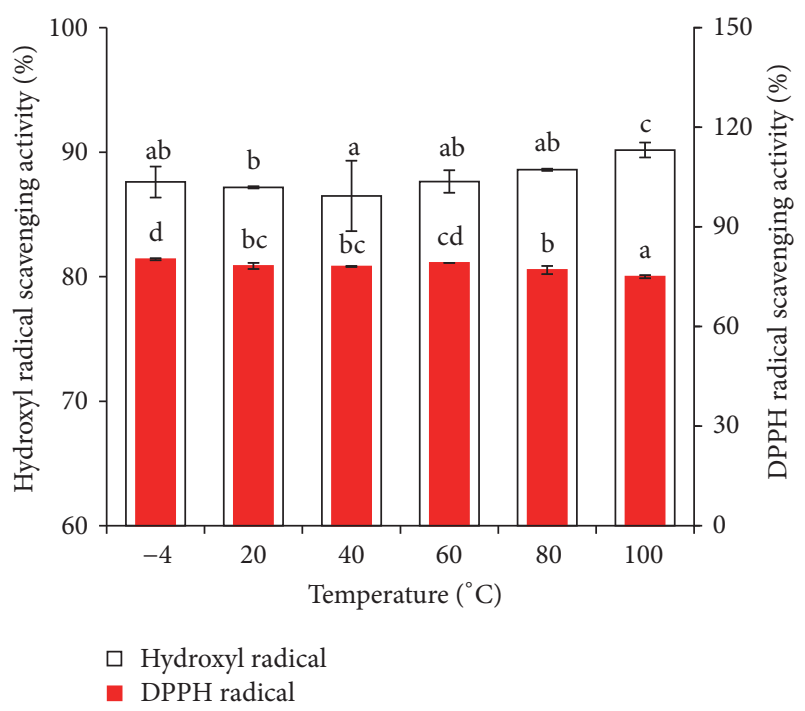

FIGURE 5: Effect of extraction temperature on antioxidant activity of MPHs. Different letters indicate significant differences between groups $(P<0.05)$.

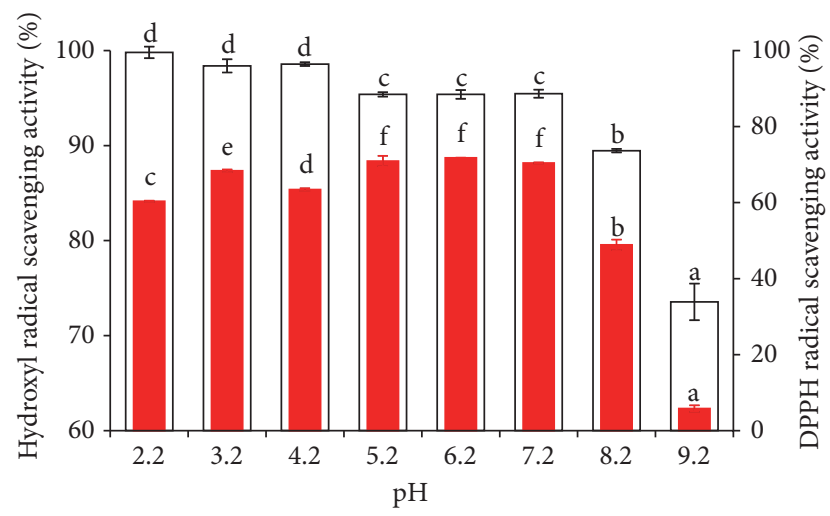

$\square$ Hydroxyl radical

- DPPH radical

Figure 6: Effect of $\mathrm{pH}$ on antioxidant activity of MPHs. Different letters indicate significant differences between groups $(P<0.05)$.

number of freeze-thaw cycles increased. Maybe the protein or peptide degradation has reduced the antioxidant activity; on the other hand, structure and conformation of protein or peptide would change with rapid changes in temperature that might affect the antioxidant activity. However, in our study, we found that the DPPH scavenging activity was only reduced by $0.05 \%$ at the sixth freeze-thaw cycle in Figure 7 , and hydroxyl radical scavenging activity also has little change with the freeze-thaw cycle increasing, which indicated that freeze-thaw cycles had little effect on the antioxidant activity of MPHs. We inferred that MPHs has high antioxidant activity stability along with the temperature shock, but we found white precipitation in the sample, likely from protein denaturation and precipitation caused by low temperatures. Therefore, although the result indicated that MPHs could be stored in low temperature conditions over multiple freeze-thaw cycles, we also should reduce the number of freeze-thaw cycles to avoid the generation of precipitation.

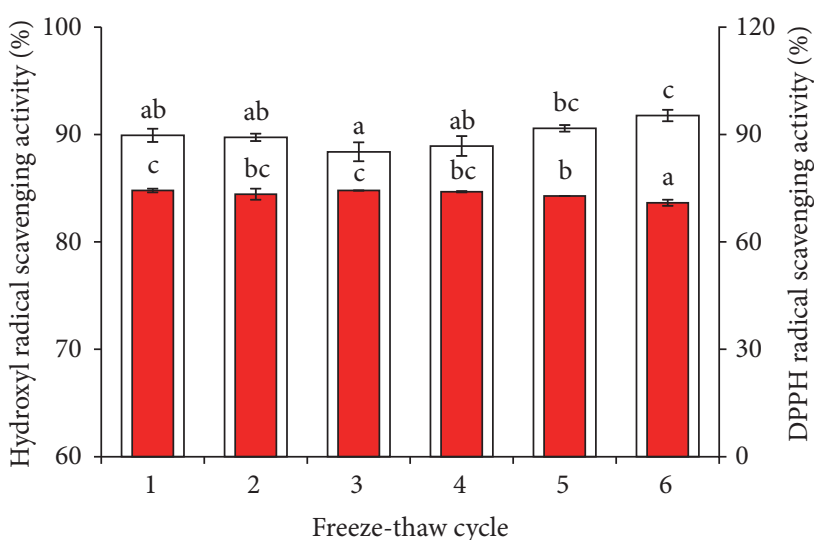

Hydroxyl radical

DPPH radical

FIGURE 7: Effect of freeze-thaw cycle on antioxidant activity of MPHs. Different letters indicate significant differences between groups $(P<0.05)$.

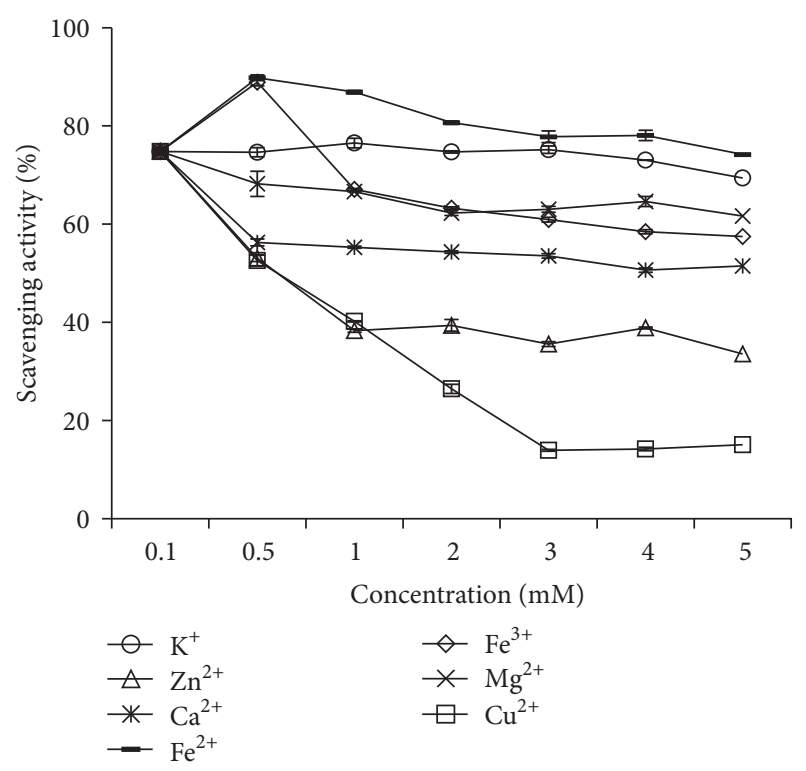

FIGURE 8: Effect of metal ion on DPPH radical scavenging activity of MPHs.

3.4.4. Effect of Metal Ions on the Antioxidant Activity of MPHs. During food processing, metal ions are always preset in the ingredients used for food product preparation. Therefore, evaluation of their influence in food materials is essential. Thanonkaew et al. [43] examined the effect of different metal ions at various concentrations on lipid oxidation of muscle protein in cuttlefish (Sepia pharaonis), determining that $\mathrm{Fe}^{2+}$ induced lipid oxidation most effectively, and $\mathrm{Cu}^{+}, \mathrm{Cu}^{2+}$, and $\mathrm{Cd}^{2+}$ displayed negligible effects on lipid oxidation. Dawidowicz and Olszowy [44] have reported that iron and copper significantly influence the estimated antioxidant activity in an ABTS assay.

As shown in Figure 8, we found that all the tested metal ions had an effect on the DPPH radical scavenging activity of MPHs. $\mathrm{Fe}^{2+}, \mathrm{K}^{+}, \mathrm{Mg}^{2+}, \mathrm{Ca}^{2+}$, and $\mathrm{Fe}^{3+}$ had little effect on the DPPH scavenging activity of MPHs; for example, 


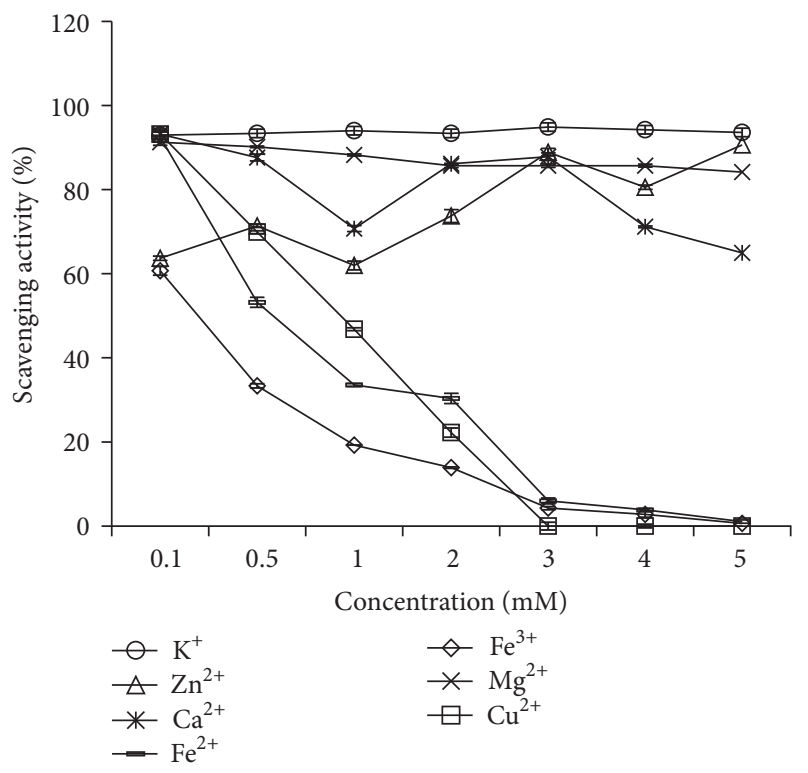

FIGURE 9: Effect of metal ion on hydroxyl radical scavenging activity of MPHs.

when the $\mathrm{Fe}^{2+}$ concentration increased from $0.1 \mathrm{mM}$ to $5 \mathrm{mM}$, the DPPH antioxidant activity of MPHs was reduced from $74.8 \%$ to $57.5 \%$. On the contrary, $\mathrm{Zn}^{2+}$ and $\mathrm{Cu}^{2+}$ notably reduced DPPH scavenging activity; for example, when the concentrations of $\mathrm{Zn}^{2+}$ and $\mathrm{Cu}^{2+}$ were $5 \mathrm{mM}$, the DPPH antioxidant activity of MPHs was reduced by $41.2 \%$ and $59.7 \%$, respectively. This result indicated that $\mathrm{Zn}^{2+}$ and $\mathrm{Cu}^{2+}$ had a negative effect on the DPPH scavenging activity on MPHs. Dawidowicz and Olszowy [45] had indicated that the presence of metal ions in the measuring system blocks the scavenging process of DPPH radicals. Furthermore, Dawidowicz et al. [46] also studied that the increase of $\mathrm{Cu}^{2+}$ and $\mathrm{Fe}^{3+}$ concentration caused an almost linear deceleration of the $\mathrm{DPPH}^{*}$ /antioxidant reaction kinetics, and the change of the reaction can be attributed to the formation of metal complexes with the components of measuring system.

Also, it is well known that hydroxyl radical is highly reactive and attacks proteins, DNA, and almost any biological molecule it touches. The damage may cause cancer, atherosclerosis, and neurodegenerative diseases [47]. Hence, the activity of scavenging hydroxyl radical is an important indicator for the antioxidant activity.

As shown in Figure 9, different metal ions had distinctly different effects on the hydroxyl radical scavenging activity of MPHs. $\mathrm{K}^{+}, \mathrm{Zn}^{2+}, \mathrm{Ca}^{2+}$, and $\mathrm{Mg}^{2+}$ had little effect on hydroxyl radical scavenging activity and they had no dosedependent effect. However, $\mathrm{Fe}^{2+}, \mathrm{Fe}^{3+}$, and $\mathrm{Cu}^{2+}$ had a clear effect, especially at high concentrations, where the hydroxyl radical scavenging activity was almost lost; for example, when the concentrations of $\mathrm{Fe}^{2+}, \mathrm{Fe}^{3+}$, and $\mathrm{Cu}^{2+}$ were $5 \mathrm{mM}$, the hydroxyl radical antioxidant activity of MPHs was reduced by $91.5 \%, 60 \%$, and $93.2 \%$, respectively. It was probable that metal ions could catalyze $\mathrm{H}_{2} \mathrm{O}_{2}$ to produce more hydroxyl radicals, thus decreasing the hydroxyl radical scavenging activity of MPHs. This result showed that, in the MPH production process, the sample should avoid mixing with $\mathrm{Fe}^{2+}, \mathrm{Fe}^{3+}, \mathrm{Zn}^{2+}$, and $\mathrm{Cu}^{2+}$.

\section{Conclusions}

In this work, conditions of peptides extraction from mackerel protein were optimized by a CCD, and the optimum extraction conditions were as follows: enzyme concentration of $1726.85 \mathrm{U} / \mathrm{g}, \mathrm{pH}$ of 7.00 , temperature of $39.55^{\circ} \mathrm{C}$, time of $5.5 \mathrm{~h}$, and water/material ratio of $25: 1$. The highest yield of DPPH scavenging activity was at $79.14 \%$. The $3 \mathrm{D}$ response surfaces showed that the enzyme concentration should control below $1800 \mathrm{U} / \mathrm{g}$; the higher enzyme concentration was costly and could reduce the antioxidant activity. In addition, DPPH scavenging activity increased slightly when the extraction time increased from 4 to $5.5 \mathrm{~h}$; this means that the DPPH scavenging activity was stable in $4 \mathrm{~h}$ later; then we should do more experiment about the extraction time below $4 \mathrm{~h}$, because too long reaction time was consuming more energy in application. Furthermore, in our study, the water/material ratio was $25: 1$. The higher water/material ratio may decrease the concentration of the enzyme and affect the hydrolysis result, and a higher solvent volume will be outweighed by the difficultly of having to handle the extra volume of solvent. Besides, the antioxidant stability tests indicated that the MPHs were resistant to high temperature and not suitable for used in alkaline condition. Furthermore, the MPHs were sensitive to metal ions of $\mathrm{Fe}^{2+}, \mathrm{Fe}^{3+}, \mathrm{Zn}^{2+}$, and $\mathrm{Cu}^{2+}$, which were the essential trace element in the human body; further research should focus on reducing the influence of the metal ions mentioned above on MPHs.

\section{Competing Interests}

The authors declare that there is no conflict of interests regarding the publication of this paper.

\section{Acknowledgments}

The study was supported by the National Natural Science Foundation of China (no. 41506175) and the Science and Technology Development Program of Shandong Province (no. 2014GGH215006).

\section{References}

[1] R. J. Elias, S. S. Kellerby, and E. A. Decker, "Antioxidant activity of proteins and peptides," Critical Reviews in Food Science and Nutrition, vol. 48, no. 5, pp. 430-441, 2008.

[2] M. R. V. Fernandes, A. E. C. S. Azzolini, M. L. L. Martinez, C. R. F. Souza, Y. M. Lucisano-Valim, and W. P. Oliveira, "Assessment of antioxidant activity of spray dried extracts of Psidium guajava leaves by DPPH and chemiluminescence inhibition in human neutrophils," BioMed Research International, vol. 2014, Article ID 382891, 10 pages, 2014.

[3] G.-M. Marcela, R.-G. Eva, R.-R. M. Del Carmen, and M.-E. Rosalva, "Evaluation of the antioxidant and antiproliferative effects of three peptide fractions of germinated soybeans on 
breast and cervical cancer cell lines," Plant Foods for Human Nutrition, vol. 71, no. 4, pp. 368-374, 2016.

[4] C. S. F. Bah, A. E.-D. A. Bekhit, A. Carne, and M. A. McConnell, "Composition and biological activities of slaughterhouse blood from red deer, sheep, pig and cattle," Journal of the Science of Food and Agriculture, vol. 96, no. 1, pp. 79-89, 2016.

[5] R. Jónsdóttir, M. Geirsdóttir, P. Y. Hamaguchi, P. Jamnik, H. G. Kristinsson, and I. Undeland, "The ability of in vitro antioxidant assays to predict the efficiency of a cod protein hydrolysate and brown seaweed extract to prevent oxidation in marine food model systems," Journal of the Science of Food and Agriculture, vol. 96, no. 6, pp. 2125-2135, 2016.

[6] C.-F. Chi, F.-Y. Hu, B. Wang, Z.-R. Li, and H.-Y. Luo, "Influence of amino acid compositions and peptide profiles on antioxidant capacities of two protein hydrolysates from skipjack tuna (Katsuwonus pelamis) dark muscle," Marine Drugs, vol. 13, no. 5, pp. 2580-2601, 2015.

[7] J. Borawska, M. Darewicz, M. Pliszka, and G. E. Vegarud, "Antioxidant properties of salmon (Salmo salar L.) protein fraction hydrolysates revealed following their ex vivo digestion and in vitro hydrolysis," Journal of the Science of Food and Agriculture, vol. 96, no. 8, pp. 2764-2772, 2016.

[8] K. A.-M. Donnelly, M. Thakur, and J. Sakai, "Following the mackerel-cost and benefits of improved information exchange in food supply chains," Food Control, vol. 33, no. 1, pp. 25-31, 2013.

[9] S. Yarnpakdee, S. Benjakul, H. G. Kristinsson, and S. Maqsood, "Effect of pretreatment on lipid oxidation and fishy odour development in protein hydrolysates from the muscle of Indian mackerel," Food Chemistry, vol. 135, no. 4, pp. 2474-2482, 2012.

[10] V. Ferraro, A. P. Carvalho, C. Piccirillo, M. M. Santos, P. M. Castro, and M. E. Pintado, "Extraction of high added value biological compounds from sardine, sardine-type fish and mackerel canning residues-a review," Materials Science and Engineering C: Materials for Biological Applications, vol. 33, no. 6, pp. 3111-3120, 2013.

[11] S. A. Sheriff, B. Sundaram, B. Ramamoorthy, and P. Ponnusamy, "Synthesis and in vitro antioxidant functions of protein hydrolysate from backbones of Rastrelliger kanagurta by proteolytic enzymes," Saudi Journal of Biological Sciences, vol. 21, no. 1, pp. 19-26, 2014.

[12] G. Saha and K. P. Biligiri, "Cracking performance analysis of asphalt mixtures using response surface methodology: experimental investigations and statistical optimization," Materials and Structures, vol. 50, no. 1, article 33, 2017.

[13] H.-L. Jiang, J.-L. Yang, and Y.-P. Shi, "Optimization of ultrasonic cell grinder extraction of anthocyanins from blueberry using response surface methodology," Ultrasonics Sonochemistry, vol. 34, pp. 325-331, 2017.

[14] M. Ovissipour, A. Abedian Kenari, A. Motamedzadegan, and R. M. Nazari, "Optimization of enzymatic hydrolysis of visceral waste proteins of yellowfin tuna (Thunnus albacares)," Food and Bioprocess Technology, vol. 5, no. 2, pp. 696-705, 2012.

[15] L. Liu, Y. Wang, C. Peng, and J. Wang, "Optimization of the preparation of fish protein anti-obesity hydrolysates using response surface methodology," International Journal of Molecular Sciences, vol. 14, no. 2, pp. 3124-3139, 2013.

[16] J. C. Rodríguez-Díaz, L. E. Kurozawa, F. M. Netto, and M. D. Hubinger, "Optimization of the enzymatic hydrolysis of Blue shark skin," Journal of Food Science, vol. 76, no. 7, pp. C938C949, 2011.
[17] Q.-L. Shi, C.-H. Xue, Y. Zhao, Z.-J. Li, X.-Y. Wang, and D.L. Luan, "Optimization of processing parameters of horse mackerel (Trachurus japonicus) dried in a heat pump dehumidifier using response surface methodology," Journal of Food Engineering, vol. 87, no. 1, pp. 74-81, 2008.

[18] P.-F. Wang, G.-R. Huang, and J.-X. Jiang, "Optimization of hydrolysis conditions for the production of iron-binding peptides from mackerel processing byproducts," Advance Journal of Food Science and Technology, vol. 5, no. 7, pp. 921-925, 2013.

[19] O. A. Janna, A. K. Khairul, and M. Maziah, "Anthocyanin stability studies in Tibouchina semidecandra L.," Food Chemistry, vol. 101, no. 4, pp. 1640-1646, 2007.

[20] C.-Z. Zhu, W.-G. Zhang, Z.-L. Kang, G.-H. Zhou, and X.-L. Xu, "Stability of an antioxidant peptide extracted from Jinhua ham," Meat Science, vol. 96, no. 1, pp. 783-789, 2014.

[21] A. Singh, S. Adak, S. Karmakar, and R. Banerjee, "Impact of processing condition on nutraceutical potency of soy whey hydrolysate," Journal of Food Quality, vol. 37, no. 6, pp. 403-414, 2014.

[22] K. Elavarasan, B. A. Shamasundar, F. Badii, and N. Howell, "Angiotensin I-converting enzyme (ACE) inhibitory activity and structural properties of oven- and freeze-dried protein hydrolysate from fresh water fish (Cirrhinus mrigala)," Food Chemistry, vol. 206, pp. 210-216, 2016.

[23] X. Wang, R. Xing, S. Liu et al., "Purification and characterization of novel antioxidant peptides of different molecular weights from mackerel Pneumatophorus japonicus protein hydrolysate," Chinese Journal of Oceanology and Limnology, vol. 33, no. 1, pp. 159-168, 2014.

[24] C.-B. Ahn, J.-Y. Je, and Y.-S. Cho, "Antioxidant and antiinflammatory peptide fraction from salmon byproduct protein hydrolysates by peptic hydrolysis," Food Research International, vol. 49, no. 1, pp. 92-98, 2012.

[25] K.-C. Hsu, G.-H. Lu, and C.-L. Jao, "Antioxidative properties of peptides prepared from tuna cooking juice hydrolysates with orientase (Bacillus subtilis)," Food Research International, vol. 42, no. 5-6, pp. 647-652, 2009.

[26] F. Guerard, M. T. Sumaya-Martinez, D. Laroque, A. Chabeaud, and L. Dufossé, "Optimization of free radical scavenging activity by response surface methodology in the hydrolysis of shrimp processing discards," Process Biochemistry, vol. 42, no. 11, pp. 1486-1491, 2007.

[27] Y. Chen, M. Wang, R. T. Rosen, and C.-T. Ho, "2,2-Diphenyl1-picrylhydrazyl radical-scavenging active components from Polygonum multiflorum Thunb.", Journal of Agricultural and Food Chemistry, vol. 47, no. 6, pp. 2226-2228, 1999.

[28] L. You, M. Zhao, R. H. Liu, and J. M. Regenstein, "Antioxidant and antiproliferative activities of loach (Misgurnus anguillicaudatus) peptides prepared by papain digestion," Journal of Agricultural and Food Chemistry, vol. 59, no. 14, pp. 7948-7953, 2011.

[29] L. Chen, L. Song, T. Li et al., "A new antiproliferative and antioxidant peptide isolated from Acra subcrenata," Marine Drugs, vol. 11, no. 6, pp. 1800-1814, 2013.

[30] Z.-Y. Zhao, Q. Zhang, Y.-F. Li, L.-L. Dong, and S.-L. Liu, "Optimization of ultrasound extraction of Alisma orientalis polysaccharides by response surface methodology and their antioxidant activities," Carbohydrate Polymers, vol. 119, pp. 101109, 2015.

[31] K. Feng, W. Chen, L. Sun et al., "Optimization extraction, preliminary characterization and antioxidant activity in vitro 
of polysaccharides from Stachys sieboldii Miq. tubers," Carbohydrate Polymers, vol. 125, pp. 45-52, 2015.

[32] J. Ren, M. Zhao, J. Shi et al., "Optimization of antioxidant peptide production from grass carp sarcoplasmic protein using response surface methodology," LWT - Food Science and Technology, vol. 41, no. 9, pp. 1624-1632, 2008.

[33] M. A. Amiza, S. Nurul Ashikin, and A. L. Faazaz, "Optimization of enzymatic protein hydrolysis from silver catfish (Pangasius sp.) frame," International Food Research Journal, vol. 18, pp. 775781, 2011.

[34] X. Fang, N. Xie, X. Chen, H. Yu, and J. Chen, "Optimization of antioxidant hydrolysate production from flying squid muscle protein using response surface methodology," Food and Bioproducts Processing, vol. 90, no. 4, pp. 676-682, 2012.

[35] Y. Ji, G. Zhang, X. Li, B. Zhao, and S. Zhou, "Enzymatic hydrolysis of protein from small yellow croaker (Psendosciaena polyactis) and evaluation of its antioxidant activity," Journal of Food Biochemistry, vol. 37, no. 3, pp. 278-285, 2013.

[36] K. W. Kong, S. Mat-Junit, N. Aminudin, F. A. Hassan, A. Ismail, and A. A. Aziz, "Protective effects of the extracts of Barringtonia racemosa shoots against oxidative damage in HepG2 cells," PeerJ, vol. 4, article e1628, 2016.

[37] S. Y. Naqash and R. A. Nazeer, "Antioxidant and functional properties of protein hydrolysates from pink perch (Nemipterus japonicus) muscle," Journal of Food Science and Technology, vol. 50, no. 5, pp. 972-978, 2013.

[38] X. Q. Wang, R. Xing, Z. Y. Chen, H. H. Yu, R. F. Li, and P. C. Li, "Effect and mechanism of mackerel (Pneumatophorus japonicus) peptides for anti-fatigue," Food \& Function, vol. 5, no. 9, pp. 2113-2119, 2014.

[39] H. Korhonen, A. Pihlanto-Leppälä, P. Rantamäki, and T. Tupasela, "Impact of processing on bioactive proteins and peptides," Trends in Food Science and Technology, vol. 9, no. 8-9, pp. 307-319, 1998.

[40] Y. Hou, J. Zhou, W. Liu, Y. Cheng, L. Wu, and G. Yang, "Preparation and characterization of antioxidant peptides from fermented goat placenta," Korean Journal for Food Science of Animal Resources, vol. 34, no. 6, pp. 769-776, 2014.

[41] C. K. Mathews and K. E. Vam-Holde, Biochemistry, The Benjamin/Cummings Publishing, 2000.

[42] R. V. Tonon, B. A. dos Santos, C. C. Couto, C. MellingerSilva, A. I. S. Brígida, and L. M. C. Cabral, "Coupling of ultrafiltration and enzymatic hydrolysis aiming at valorizing shrimp wastewater," Food Chemistry, vol. 198, pp. 20-27, 2016.

[43] A. Thanonkaew, S. Benjakul, W. Visessanguan, and E. A. Decker, "The effect of metal ions on lipid oxidation, colour and physicochemical properties of cuttlefish (Sepia pharaonis) subjected to multiple freeze-thaw cycles," Food Chemistry, vol. 95, no. 4, pp. 591-599, 2006.

[44] A. L. Dawidowicz and M. Olszowy, "Antioxidant properties of BHT estimated by ABTS assay in systems differing in $\mathrm{pH}$ or metal ion or water concentration," European Food Research and Technology, vol. 232, no. 5, pp. 837-842, 2011.

[45] A. L. Dawidowicz and M. Olszowy, "Mechanism change in estimating of antioxidant activity of phenolic compounds," Talanta, vol. 97, pp. 312-317, 2012.

[46] A. L. Dawidowicz, D. Wianowska, and M. Olszowy, "On practical problems in estimation of antioxidant activity of compounds by DPPH center dot method (Problems in estimation of antioxidant activity," Food Chemistry, vol. 131, no. 3, pp. 10371043, 2012.
[47] O. I. Aruoma, "Free radicals, oxidative stress, and antioxidants in human health and disease," Journal of the American Oil Chemists' Society, vol. 75, no. 2, pp. 199-212, 1998. 

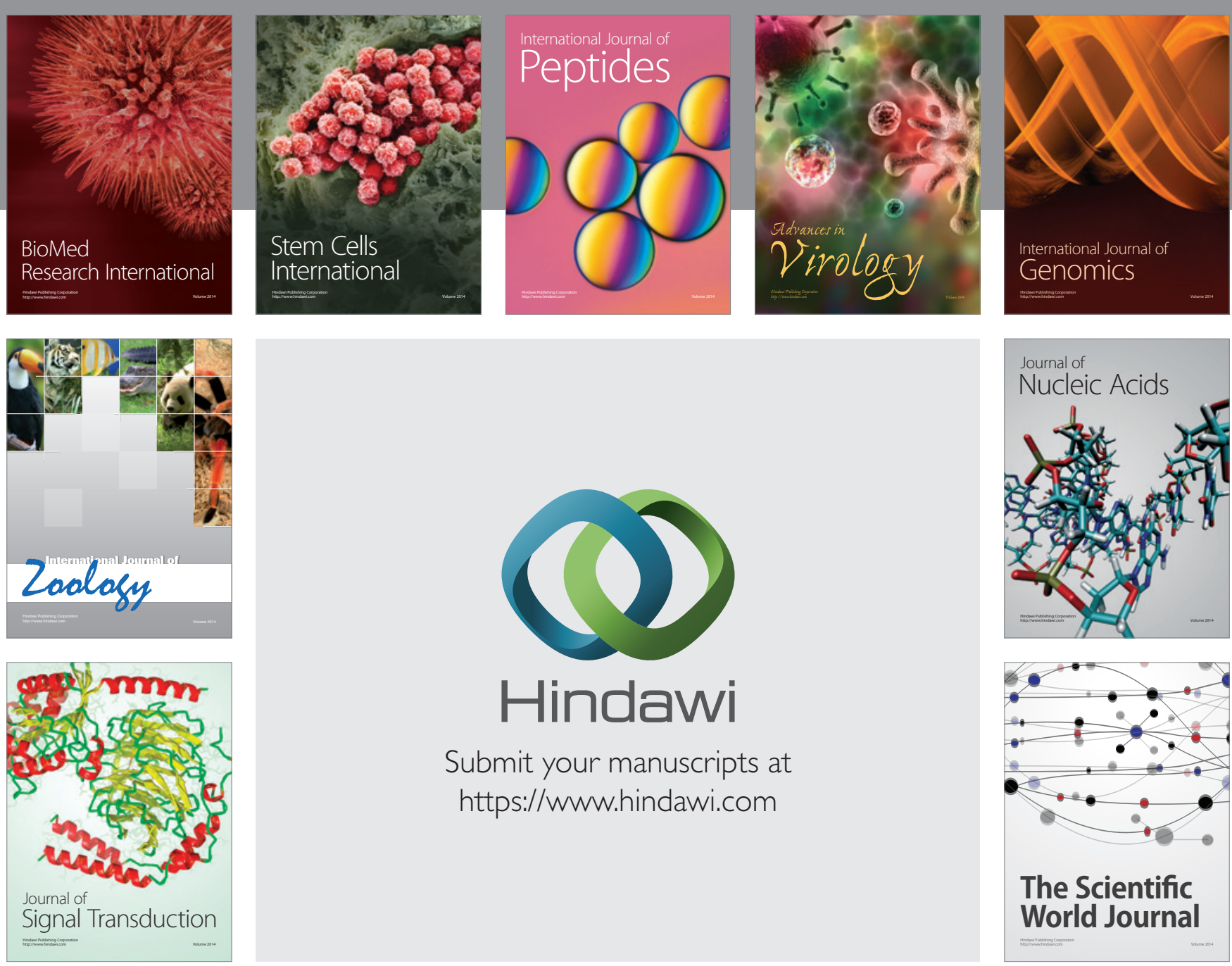

Submit your manuscripts at

https://www.hindawi.com
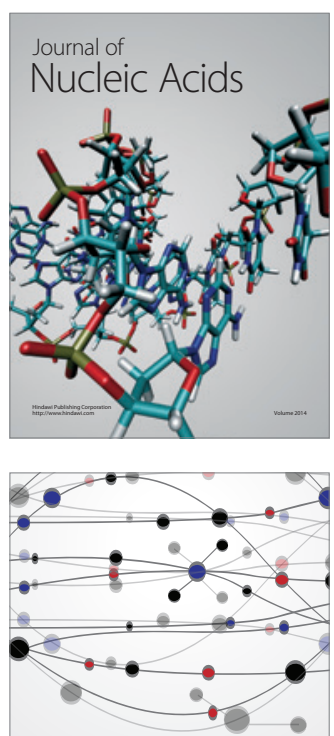

The Scientific World Journal
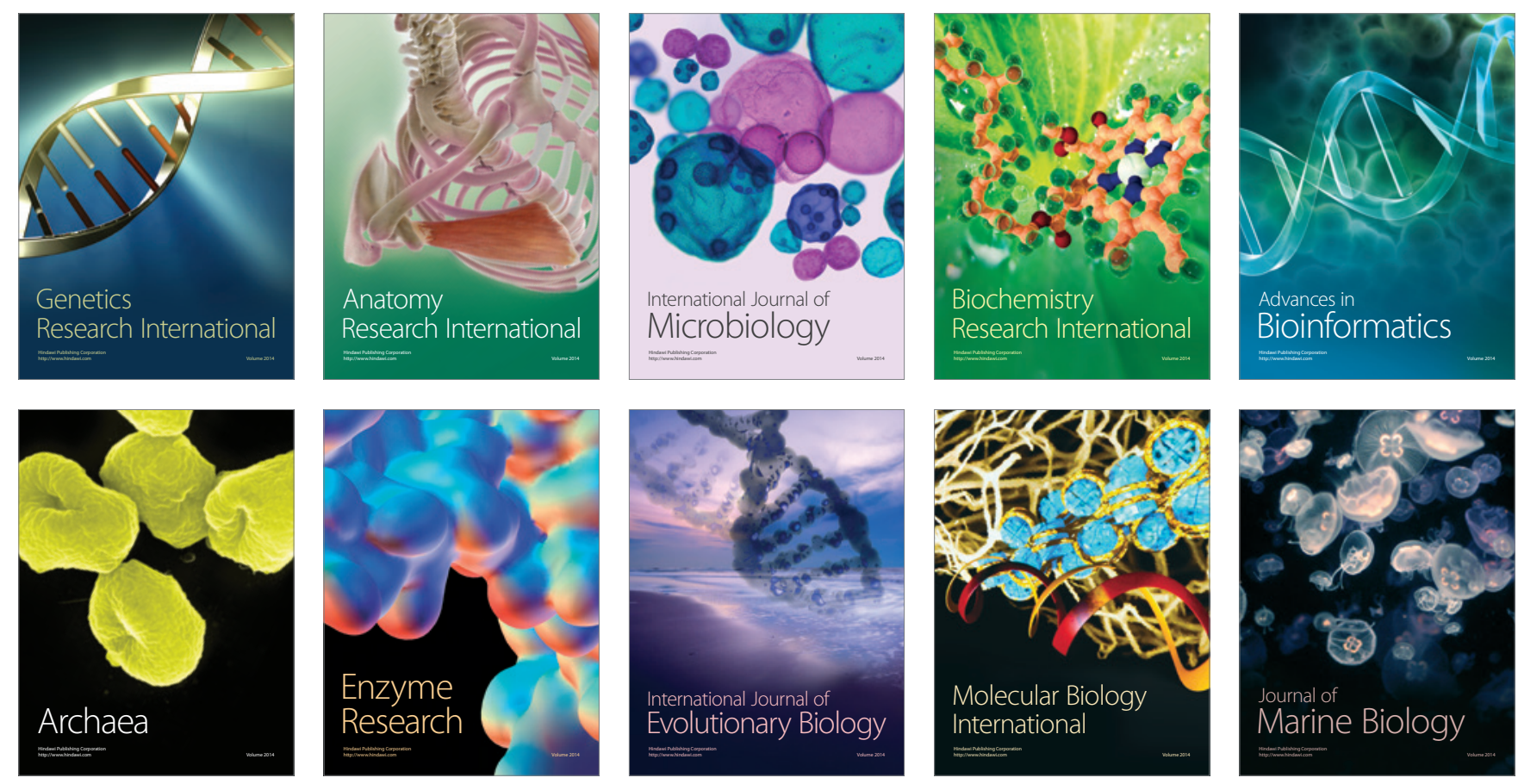